\title{
Continuidad de un compromiso social y Académico
}

\author{
Manuel $\mathrm{M}^{\mathrm{a}}$ Zorrilla Ruiz \\ Catedrático Emérito de Derecho del Trabajo y de la Seguridad Social \\ Universidad de Deusto \\ Ex-Presidente del Tribunal Superior de Justicia del País Vasco \\ Presidente de la Asociación de Jueces y Magistrados Jubilados de España
}

Recibido: 14.09 .06

Aceptado: 10.10 .06

\begin{abstract}
Resumen: De 1974 a 2003, la Cátedra de Derecho del Trabajo de la Universidad de Deusto ha organizado las Semanas de Derecho del Trabajo para analizar las principales cuestiones surgidas en el seno de esa disciplina. La transición democrática y su impacto en el Derecho Social se contemplaron en primer lugar. Se dedicó luego la atención a las transformaciones producidas en unas materias caracterizadas por su celeridad evolutiva y su acomodación a las realidades sociales. El estudio presente trata de establecer el panorama y el significado de la conciencia de las transformaciones que se sucedieron entonces. Insiste en los peligros del neoliberalismo, dañoso para la supervivencia del Derecho Social, y en la devaluación del Estado de Bienestar, ante los excesos desreguladores y los aspectos censurables de la globalización.
\end{abstract}

Palabras clave: Transición democrática. Proceso de cambio. Crisis económica. Flexibilidad. Globalización. Neoliberalismo.

\begin{abstract}
From 1974 to 2003, the Chair of Labor Law, University of Deusto, has organized the Weeks of Labor Law to analyse the main questions which have appeared in that discipline. The democratic transition and its influence on the Social Law was the matter observed in first place. Afterwards, the attention was reserved to the transformations produced in a discipline whose characteristics are the rapid and easy adaptation to the social conditions. This study tries to stablish the panorama and the meaning of the consciousness of the changes suffered. It insists on the risks of the neoliberalism, injurious for the surviving of the Social Law, and the weakness of the Welfare State, duty to the excess of the desregulation and the negative regards of the globalisation.
\end{abstract}

Key words: Democratic transition. Change. Economic crisis. Flexibility. Globalisation. Neoliberalism.

Sumario: 1. Reflexiones introductorias.-2. Reacciones y actitudes del pensamiento jurídico.-3. Carácter de una curiosidad afanosa y tenaz. -4. Recordatorio y crónica de un compromiso.- -5. Referencia a la estabilidad en el empleo.-6. Aspectos notables del Derecho Social colectivo. -7. Entorno, consecuencias y manifestaciones conflictivas de la crisis económica.-8. Eficiencia y perspectivas de la mediación jurisdiccional. -9. Fenomenología específica del sindicalismo.-10. Relativización de las acciones de tutela social.-11. Redefiniciones del derecho a la liber- 
tad de empresa.-12. Tendencia a la igualación en el progreso.-13. Ensanchamiento de los espacios sindicales.-14. Recapitulación constitucional.-15. Hacia la recepción e instalación del hecho globalizador. -16. ¿Esperar contra toda esperanza?

\section{Reflexiones introductorias}

Han superado los ejercicios de imaginación más atrevidos, la contundencia y variedad de los impactos que - a plazos cortos y perecederos, sin un terco afán de perpetuarse y prestando auxilios de urgencia- han causado, en los campos de sus respectivos planteamientos y en el curso de sus operaciones, las cuestiones polémicas del Derecho Social. Fruto de la sensibilidad ética con que -aprovechando el favor de una coyuntura de euforias y de prosperidad económica - el Estado Social y democrático de Derecho abanderó, bajo ese rótulo, la novedad de sus disciplinas. A saber, el Derecho de las relaciones individuales de trabajo, el Derecho Sindical o de las relaciones colectivas, el Derecho de la Seguridad Social y las particularidades litigiosas que, caracterizadas por su expeditividad y dinamismo, convivían con los modelos de equivalentes jurisdiccionales o sustitutivos procesales de la mediación, la conciliación y el arbitraje.

Estos sectores del ordenamiento jurídico estatal y las expresiones homólogas del ordenamiento jurídico extraestatal -entre sí concurrentes- no gozaban de la solidez y prestancia con que las valiosas instituciones del Derecho Romano se erigieron en paradigma del pensar de los juristas y de la persuasión de unos razonamientos que aunaban los valores del entendimiento y la emoción. El nuevo Derecho Social tampoco contaba con la serenidad y la pausa que -para engrosar el crédito de sus ofrecimientos- el Derecho Privado general aplicaba a la renovación de sus elementos de origen, sin que esta audacia intelectual privase a sus hallazgos -laboriosos inventos y no veleidosos arbitrios- de alcanzar larga vida y encontrar las claves que, enriqueciendo sus instituciones, demostraban su provecho social.

El Derecho de las relaciones de trabajo y sus disciplinas conexas reclaman una actividad -de apariencias urgentes, si se quiere, pero inseparable del grave compromiso adquirido con las parcelas de la familia humana- que se debe a un dato evidente. Los sectores del ordenamiento jurídico cuyos intereses evolucionan a ritmos pausados y consolidan un desarrollo saludable retienen los mínimos de estabilidad y solidez que derivan de unas realidades sociales descubiertas, entre luces y sombras, por la clarividencia políticolegislativa o accesibles en términos que, avalando la calidad del discurso de los legisladores, confirman sus merecimientos. Ha de transcurrir un espacio de tiempo, significativo y fecundo, entre los episodios que prueban el acierto de la voluntad originaria del legislador -actualizada y respetable, mientras no la frustren acontecimientos sorprendentes- y la voluntad adulta de la ley que 
procede de un cambio sustancial de la base o presuposición legislativa. Irrumpen entonces unas realidades sociales que el legislador juzgó de improbable advenimiento y/o poco dignas de tomarse en cuenta, o que, lisa y llanamente, no atinó a predecir con la exactitud y pormenor que -en pro de los intereses generales protegidos por la norma jurídica- exigían la importancia de sus apariciones y la sensibilidad precisa para no soslayarlas.

De ahí que la comprensión histórico-evolutiva de las normas jurídicas desborde el trabajo meramente interpretativo -ceñido a esclarecer mensajes oscuros o ininteligibles- y reformule -rehaciéndola en función de esas necesidades- la proposición o proposiciones deontológicas afectadas por cambios cuya notoriedad ineludible clama por un tratamiento actualizado y convincente. Las normas jurídicas -lejos de ser, como rezaba el viejo adagio, pan para hoy y hambre para mañana- incorporan un enérgico instinto de conservación que preserva sus afanes de supervivencia. Designio que, en principio, corresponde a los términos accesibles de su aplicación originalista y que, con el paso didáctico del tiempo, se beneficia de las acciones cuasilegislativas de la jurisdicción. El juez ordinario no se limita a interpretar las normas anticuadas u obsoletas, sino que -ante lo tentador del estado de cosas que le desafía- las reconstituye y ajusta al espíritu y la finalidad del momento de su aplicación.

Las soluciones que el Derecho Social ha cosechado en los conflictos que le imprimen caracter, se señalan -a causa de sus contenidos inéditos y de lo imprevisible del tiempo en que aparecen- por un componente técnico-jurídico de dificultad no menor y, sin duda, más conmovedor o existencial que el de muchas cuestiones notables del Derecho Privado. Cosa distinta es la superficialidad con que esos problemas se abordan -casi siempre por apremios del tiempo- o la austeridad del razonamiento que se les dedica. Defectos que han motivado pintorescos comentarios de los especialistas de otras disciplinas o han petrificado actitudes que -por ejemplo, en materia de la teoría de las fuentes- se han estancado sin llegar al fondo de las cosas. A la atención de nadie escapan la abundancia y apremio de los interrogantes que -inopinadamente y reclamando soluciones prontas- se adueñan del universo de las relaciones de trabajo. Sin olvidar las sucesivas señales históricas -de entusiasmo y optimismo sociales, de crisis de las economías generales, de regreso al neoliberalismo funesto- con que los desafíos de gran magnitud conmueven a la sociedad y a la opinión pública, para ocupar -sin tardanzas injustificadas y con el pertrecho intelectual de los argumentos razonables-el espacio habitable de su marco jurídico. La duración de esos conflictos -que tienden a sintetizar o disolver, no a exasperar estérilmente, los antagonismos subyacentes a su promoción y su entidad-debe y suele ser breve. A poco que sus protagonistas intenten extenderlos más allá de los límites tolerados por su patología, se seguirán daños desaconsejados por la prudencia y la templanza -que también cumplen su papel al respecto- de una estrategia sindical consciente y responsable. La excesiva prolongación o la putrefacción del 
conflicto desploma las energías sindicales y obstaculiza las salidas fundadas en la preponderancia de lo equitativo y de lo justo.

Las relaciones de producción y trabajo, dependientes antes del decisionismo de la autonomía sindical, se ven hoy castigadas por la recuperación del poder que -complotado con las agresiones de la tecnología y gracias al apoyo globalizador - ha consumado el capital. Se resienten de dificultades que crecen con inquietante rapidez. Sus celadores adivinan que las soluciones ofrecidas al precio de serios esfuerzos de gestión y celeridad de diagnóstico, se devalúan y decaen al cabo del tiempo. Decepciona la desproporción entre las dosis de racionalidad y paciencia derrochadas para perfeccionarlas -fomentando la ilusión de su continuidad- y la rapidez con que sus posibilidades se esfuman. Los adelantos y las sorpresas tecnológicas -que estimulan esta caducidad y minimizan la socialidad del Derecho aplicable- equivalen a factores endémicos y presagios de lo pésimo para los más débiles, cuando no sirven de arma letal destinada a exterminar sus proyectos. Sus adelantos aguardan apostados a la vuelta de la esquina para que -como ocurre también con el destino- se sepa, cuando menos, de sus inconvenientes, y, cuando más, se conjuren, con fortuna variable, los peligros de la entrada en bata1la. Situaciones inadvertidas o latentes -aunque expuestas a aparecer de pronto- pueden hacer interminables las vigilias de los juristas que, tras examinar esos cambios, recomiendan los arreglos de relativismo terapéutico que estiman adecuados a su calidad y tratamiento.

\section{Reacciones y actitudes del pensamiento jurídico}

El crecimiento -incontrolable en cuanto al si y el cómo -de la disciplina del Derecho Social desencadena reacciones abandonistas y académicas, más frecuentes las unas que las otras.

Constan, con solvencia estadística, la frecuencia y detalle con que -desde que se estrenó, en sus variantes o diferencias específicas, el género próximo del juicio de constitucionalidad-los recursos de amparo constitucional han agotado el tratamiento de los temas más llamativos del Derecho Social. Es éste un sector del ordenamiento jurídico cuya técnica del pensamiento de problemas incorpora semejante dato y no prescinde de su peso específico. Hay un copioso acervo de normas jurídicas que -a la hora de aplicarse para encajar el supuesto histórico en la figura típica de su imagen rectora- necesitan del complemento cuasinormativo que contiene la doctrina emanada de esta variante defensiva de la legalidad fundamental. Con preferencia, algunas veces, a la que trae causa de la jurisprudencia ordinaria.

Pese a la utilidad de sus aportaciónes - novedosas, de entrada, y acostumbradas con el tiempo- el examen de las afirmaciones centrales o razones de decidir de los jueces ordinarios no muestra una predilección excesiva por emplear el apoyo -que, a mayor abundamiento, es preceptivo- de los valo- 
res, principios y preceptos de la legalidad fundamental -algunos de confección muy laboriosa- o de los criterios hermenéuticos de su supremo intérprete. Se prefiere un uso más testimonial o intuitivo y menos técnico de esos contenidos constitucionales y de otros que se les parecen. Una tecnificación rigurosa -es decir, obediente a la letra y el espíritu de las normas constitucionales y fiel a la razón de decidir del órgano encargado de su interpretación- permitiría que, amén de los precedentes ya integrados en el Derecho objetivo, se tomase cuenta y razón de las adquisiciones, doctrinalmente sugestivas, que el Derecho Social -agraviado por el desdén de los cultivadores de otras disciplinas, pese a su regeneracionismo moralizador y a las lecciones aprendidas de sus transformaciones históricas- reivindica cargado de razón. Sus construcciones, marcadas por la celeridad, comulgan con la máxima de que la justicia tardía se convierte en justicia mal administrada y escapan a la reprobación de un mal frecuente en otros órdenes jurisdiccionales. También han de habituarse -será el tiempo testigo del fracaso o el éxito de estas insinuaciones- a situar los problemas planteados en un marco constitucional apto para dilucidarlos con la contribución del precedente -síntesis de autoridad y tradición- o de la persuasión intelectual que los jueces ordinarios pueden, si se esmeran en ello, inferir del acervo constitucional a su alcance.

No siempre se recuerda, quizás a causa de esas dificultades, que las categorías permanentes del Derecho Civil -sobre todo las de su Parte General, primer esbozo de la Teoría del Derecho, y las del Derecho de las obligaciones- son de manejo indispensable para el desarrollo y el buen fin de la aplicación de las normas del Derecho Social. Pertenecen al depósito de las garantías del acierto de su entrada en juego y también de los inconvenientes de su olvido. La obligación de recordar lo imperecedero y exigente del pasado sufre las erosiones de un desgaste que -quizás propiciado por factores extrajurídicos influyentes en la calidad de las resoluciones judiciales- explica su desmemoria dogmática y los inconvenientes que acarrea.

\section{Carácter de una curiosidad afanosa y tenaz}

La curiosidad de los especialistas -cuyo censo y preocupaciones jurídicas crecen en razón directa de grosor de aquellos desafíos- sigue pendiente de los proteicos acontecimientos del Derecho Social, y de las fuentes, la velocidad de crucero y la naturaleza de sus cambios. Están ávidos de pacificar-aun condicionados por la relatividad del concepto jurídico indeterminado que este infinitivo contiene- problemas cuyas soluciones, lejos de achicar el panorama de las inquietudes pensantes, se ven sucedidas por otras cuestiones que aumentan las dificultades. No se puede perder el mínimo detalle de una evolución que, a veces, parece atormentada y esotérica, ni dejar de observar hasta cuándo, cubiertos los objetivos pacificadores, el círculo del 
discurso jurídico prosigue abierto y expectante. A muchos problemas que dejan de serlo por la celeridad de la solución que el orden social de la jurisdicción les facilita, suceden la búsqueda y la crítica de los principios informadores de su significado, y los debates que -imprejuzgados como cuestiones colectivas sobre los intereses generales- reclaman un examen, general asimismo, que satisfaga los imperativos de la seguridad jurídica. Cabe incluso que, al sanearse las posturas irreconciliables del caso litigioso, esa suerte de seguridad - patente en los efectos de la cosa juzgada material- deje otros cabos sueltos que tardan lo suyo, si al final lo consiguen, en cerrar sus definitivas ataduras.

No en vano, como se ha subrayado, una distinción clarividente separaba la presurosa andanza del Derecho Social -en incesante combustión de etapas- de la templanza equitativa del Derecho Romano y de la altanería -modernizante y progresiva- del Derecho Civil. Antes de emerger los actuales rasgos de su perversión por el virus diabólico del neoliberalismo, el Derecho Social era una disciplina -paradójicamente, menos disciplinada o poco rígida- que, ante lo inaplazable de proteger los intereses que se le encomendaban, reaccionaba con la presteza y efectividad que exigían los signos de los tiempos. Sin subordinar sus soluciones a la adquisición de niveles pulquérrimos de reflexión, cuyos fracasos prueban que lo mejor suele ser enemigo de lo bueno, ha realizado los esfuerzos - de proporciones medias- que, en cada circunstancia, conjugaban el prosaísmo de las cuestiones traídas a debate con la delicadeza técnico-jurídica de los criterios adoptados y con la aplicación de los remedios que instaban las auténticas demandas sociales.

\section{Recordatorio y crónica de un compromiso}

Las reflexiones siguientes -comprensivas de la que, según sus propósitos, cabe llamar continuidad de un compromiso social y académico- son un volver la vista atrás, porque así lo han querido los imperativos del tiempo docente, pero nunca una despedida irrevocable ni un resignado adiós a las experiencias de una iniciativa que arroja un saldo gratificante y positivo. El resultante de haber librado y ganado, al menos, la batalla de seis lustros que abarcan importantes mudanzas habidas en el campo del Derecho Social. Aquella rúbrica que, fuera de cualquier casualidad, pretendía fijar la longitud de onda de los esfuerzos pensantes a que dio lugar, ayudó a diseñar la imagen -desconcertante, a veces, pero aleccionadora, como reflejo, que era, de los episodios de un cambio sustancial en la Política y la estructura del Estado- de las transformaciones que el Derecho Social acusaba y de la recepción de los correspondientes cuerpos de doctrina. Se intenta hacer, con ello, un inventario, ni siquiera un balance, de lo que -siendo a la vasta historia del Derecho de las relaciones de trabajo lo que una gota de agua a las inmensidades oceánicas- fueron y significaron las 30 jornadas que, desde el 
curso académico 1973-1974 hasta el 2002-2003, ambos inclusive, constituyeron las celebraciones anuales ordinarias de las Semanas de Derecho del Trabajo de la Universidad de Deusto y en las que, con carácter extraordinario, se interpuso, la que, a finales de 1988, precedió a la inauguración del Instituto de Estudios Sociolaborales de ese centro. Semanas que organizó la Cátedra de Derecho del Trabajo y de la Seguridad Social de la Facultad de Derecho, con la iniciativa originaria de su Decanato, y a la que, andando el tiempo y en función de las referencias que lo aconsejaban, se sumaron las contribuciones institucionales del propio Instituto de Estudios Sociolaborales, del Consejo General del Poder Judicial, de la Universidad Montesquieu de Burdeos (Francia), de la Universidad de Lodz (Polonia), de la Universidad Católica de Recife y del Instituto Pernambucano de Derecho del Trabajo (Brasil). A ellas se añadieron, como invitados a título individual, las intervenciones de los especialistas más notables del Derecho Social en los ámbitos de la Universidad, del Poder Judicial, de la Justicia Constitucional y del ejercicio interdisciplinar de las profesiones jurídicas y las variantes económicas. Intentar mencionarlos nominativamente - con el riesgo de silenciar a uno sólo de cuantos prestaron su apoyo y su conocimiento- supondría un agravio del que la mala memoria no serviría de suficiente justificación. Todos ellos supieron de la estima con que se acogió su presencia, se agradeció su generosidad y se asimilaron los frutos de su sabiduría en las peripecias de una transformación histórica que atribuyó un valor excepcional a su contribución.

Para salvar esa fidelidad y honrar su condición de promesa solemne, se reiteró hasta la extenuación -en el curso de las anualidades universitarias y a la medida de los útiles y oportunidades disponibles- la doble finalidad de estos actos. De una parte, el cumplimiento de un compromiso contraído con la sociedad pluralista, destinataria y paciente del enmarañado acervo jurídico sobre el que se discurría. De otra, la obligación adquirida frente a un mundo académico que, acentuando su curiosidad y voluntad de escrutar los fenómenos del Derecho Social, se acercaba a las experiencias de su aplicación y a los paradigmas familiarizados con la inquietud de los juristas. Era preciso que -haciendo historia fiel de unas innovaciones tan sugestivas como inéditas- la sociedad asumiese la preocupación por los temas y/o aspectos de las relaciones de trabajo que, además de afectar a las necesidades, tangibles e inmediatas, de sus pobladores, destacaban la complejidad técnica y el provecho social que en ellos concurrían.

También cundía la exigencia de que el alumnado de la Facultad de Derecho y, no menos, las personas o grupos interesados, conociesen los pareceres -convergentes o contradictorios-que los especialistas -teóricos y prácticos- del Derecho Social emitían en vista de esos cambios. Lo hicieron, primero, en el contexto de un sistema paternalista autoritario, cuya peculiar Política Social acusaba los defectos imitados de los modelos contemporáneos -tiempo atrás perecidos- que les inspiraron. Lo hicieron después ante la 
expectación despertada por el nacimiento de un Estado social y democrático de Derecho, cuyo certificado de defunción - por lo que hace al primero de sus atributos conceptuales- figura entre los objetivos capitales de un pensamiento y una acción hoy confundidos por la depredación y la objetable moralidad de las especies globalizadoras. La experiencia autóctona había surgido tardíamente de las luces y sombras de una transición-rectius, regeneración-democrática que, acudiendo a una modalidad castiza de uso alternativo del Derecho, sustituyó el radicalismo de la ruptura traumática, por el arbitrio pacificador de una reforma reconciliadora que, con ventaja y oportunidad, hizo sus veces. Aunque, de nuevo, un pensamiento débil y demoledor ponga en tela de juicio la sanidad y perfección de ese proceso.

De ahí, la pluralidad de cuestiones que -atisbadas en el horizonte constitutivamente histórico de la razón práctica o surgidas, de súbito, con luz cegadora- impresionaban por lo sorprendente y, a veces, fugaz de su fisonomía. Sus repercusiones colectivas aceleraban la premura de despejar sus dudas, adoptando criterios purgados de errores técnico-jurídicos y/o demoras dañosas para la estabilidad del orden político y la tutela del interés social. Esas aportaciones merecen un especial recuerdo que va más lejos de la gratitud superficial. El esfuerzo y el tiempo que les dedicaron sus autores satisfacían, con devoción muy superior a la de otros problemas contemporáneos del Derecho, unas demandas sociales de vanguardia que, restituyendo su sonoridad, al clamor apagado de las voces sin voz, confiaban en ser oídas efectiva e inaplazablemente.

Las consideraciones siguientes recogen y refunden las líneas generales de las reflexiones que, por su sucesión cronológica y al hilo de las transformaciones político-sociales, acreditan la continuidad de ese compromiso social y académico que operó durante un tiempo duradero y revelador de las novedades que fueron surgiendo.

\section{Referencia a la estabilidad en el empleo}

Los datos procedentes de un mundo de relaciones de trabajo caracterizado por la decadencia de la -anacrónica y terca-obsesión autoritaria disentían de las pautas liberalizadoras que, atendiendo a la naturaleza de las cosas, observaban los países industralizados de Occidente para adaptar el volumen de las ofertas hechas a los consumidores en el mercado de libre competencia -dependientes de las previsiones sobre su absorción por la demanda de bienes y servicios- a dos elementos concurrentes. Uno era la dosis de fuerza de trabajo que, demandando ocupación en el mercado de empleo, se reclutaba, sin desmerecimientos económicos, hasta los límites de una sobredimensión que señalaba los umbrales de la ocupación efectiva. El otro afectaba a la duración de las relaciones individuales constituidas, por vía contractual, para lograr una acomodación equilibrada y evitar situaciones de mora -indi- 
vidual o colectiva- de los acreedores de trabajo. La satisfacción de esa demanda se explicaba por la voluntad de poner coto a su marginación o transferencia a otros mercados, pero también para que los contenidos económicos de la libertad de empresa no sufriesen la carga de remunerar a los trabajadores de una plantilla inactiva por motivos que escapaban a una diligente previsión o, más crudamente, por la rigidez de la contratación por tiempo indefinido. El gravamen de las sobredimensiones de plantilla enrarecía y elevaba a la segunda potencia los episodios de desocupación colectiva. Anunciando la puesta en escena de la que se llamaría luego flexibilidad laboral, no alteraban un ápice las reacciones del régimen autoritario que, aferrado a los anacronismos del principio de estabilidad en el empleo, quería compensar, pese a lo frecuente de sus efectos negativos, la falta de las garantías exigibles en el plano de las relaciones colectivas.

Conviene aludir a los temas que más notoriamente se abordaron, con la vista puesta en esos objetivos y en la fenómenología que desencadenaron. La frecuencia de la llamada cesión ilegal de mano de obra-reprobada a causa del vejamen que sus prácticas irrogaban a la cosmoeminencia de la persona individual y a la libertad de trabajo- no era la misma en todas las variantes que, sin afinar demasiado, compartían ese título de censura. Había que separar los rictus de su rostro inhumano -que degradaba el hecho del trabajo a la condición de mercancía- de otras hipótesis que, aunque similares a primera vista, diferían de la rudeza de esa especialidad. Suponían formas de contratación o subcontratación de servicios a que los países industrializados con economía de mercado recurrían para encarar los retos de la crisis económi$c a$-en cuya presencia, el sistema paternalista autoritario reaccionaba con la impavidez de una esfinge- y valorar la eficacia de los nuevos factores que ocupaban el círculo pacífico de los experimentos del diálogo social. Mediaba el convencimiento -aplastante y unánime- de que la gravedad del estado de cosas nacido de la crisis económica y apreciado en la esfera social europea, obligaba a un cambio de rumbo que, aunque provisional en apariencia, favorecía la explotación neoliberal del éxito y condenaba a entenderse a los sujetos de unas relaciones antagónicas. Relaciones nerviadas, al cabo de una larga lucha, por un dogma de fe -el principio de irregresividad de las adquisiciones sociales- que, como irrenunciable regla de oro, garantizaba su consolidación. El sistema político paternalista y el sindicalismo vertical -geográficamente cercanos e ideológicamente distantes de los espacios industriales de la democracia- desoían las voces de alarma que, venidas del agujero negro de la autarquía económica, escapaban a su falta de voluntad e incapacidad de entendimiento.

La legalización democrática de las empresas de trabajo temporal facilitaría la introducción de supuestos afines, pero no idénticos a los groseros experimentos de tráfico ilegal de mano de obra que coexistían con otros de traza menos censurable y que, a falta de criterios unificadores, no recibían igual trato de las jurisdicciones que enjuiciaban sus manifestaciones conflic- 
tivas. Pese a la tipificación general de los delitos contra la seguridad en el trabajo, la estadística de su represión penal era poco menos que una página en blanco ante la inanidad de los empeños en que las acusaciones públicas los persiguieran con alguna coherencia. La jurisdicción contencioso-administrativa reaccionaba con una severidad sensata al revisar los actos de ejercicio de la potestad sancionadora que, verificada la cesión ilegal de mano de obra, emprendían los órganos competentes de la Administración Pública. La jurisdicción de trabajo aportó pormenores y matices que, sin presumir de una perfección impecable, presagiaban aspectos de la futura flexibilidad laboral. Un acaecimiento históricamente indivisible y unico determinaba calificaciones divergentes y reñidas con la contundencia-una cosa no puede ser y dejar de ser al mismo tiempo-del principio ontológico de no contradicción.

La especie químicamente pura de cesión ilegal -consistente en la enajenación lucrativa de la fuerza de trabajo- resucitó una idea que había despertado la atención de los civilistas dedicados a estudiar el tema de la distinción entre derechos reales y derechos de crédito, y a reducir sus diferencias. Admitían que incluso los derechos de crédito podían vulnerarse por actos u omisiones de personas extrañas a la relación jurídica que los incorporaba. La cesión ilegal de mano de obra -cuya naturaleza jurídica mixta combinaba las categorías de la simulación relativa y el fraude de ley- se enfocó desde esta perspectiva, para facilitar el diagnóstico del fenómeno e intentar su exterminio. Había que proteger la estabilidad en el empleo lesionada, si, al extinguirse los contratos simulados de prestación de servicios o ejecución de obra, el cedente de mano de obra daba por acabadas las relaciones -de traza visiblemente temporal-convenidas con trabajadores que, pese a la ficción disuasoria, llevaban sólo a cabo las tareas permanentes y habituales del ciclo productivo de la empresa principal. Concurrían en ellos -pese a lo atado y bien atado del disfraz de la simulación- los requisitos de una relación individual de trabajo que -en vez de vincularles a la empresa cedente que decía cumplir la carga de darles ocupación efectiva- les ligaba al empleador cesionario que organizaba y dominaba el proceso económico de transformación. De ahí, las figuras de morfología compleja o variantes de cesión a la carta.

La leva de operarios o cesión ilegal propiamente dicha databa de la confabulación rudimentaria de personas físicas que, sin ser empleadores ni pretender asumir este carácter, disponían del esfuerzo manual de aquellos cuyas voluntades suplantaban al servicio de los cesionarios. La contratación por terceros, ayuna de proceso productivo autónomo y acompañada de la cesión, arrancaba de un convenio fraudulento entre el empresario verdadero y el empresario falso. La contratación con proceso propio desfigurado por el préstamo dimanaba de la confabulación de verdaderos empresarios que, con habilidad antisocial, dotaban de aspecto respetable a la tosquedad de la leva de operarios. La cesión inducida o provocada venía del acuerdo que el verdadero empresario y uno o varios de sus trabajadores concluían para subor- 
dinar la vigencia de la relación laboral a la duración del arrendamiento de servicios que, a primera vista, mediaba entre unos y otros.

Sorprendió que -nada más incoada la transición democrática- continuara su curso el proceso legislativo de regulación de las relaciones laborales, cuya aprobación fue posible gracias a la votación parlamentaria de todos los componentes del Gobierno que, como un solo hombre, cumplieron las instrucciones recibidas y evitaron el fracaso que se presentía. El texto -vigente en virtud de una exigua mayoría numeral- no se condecía con el signo de la renovación esperado y dejaba en pie demasiados residuos anacrónicos del extinto sistema autoritario. Reiteraba -caído el telón del escenario de la representación de dicho régimen- una sobreprotección de la estabilidad en el empleo que el sistema anterior -condescendiente hasta el hartazgo, con las avideces económicas del empresariado- no llevó a sus últimas y naturales consecuencias. Aun cuando había defendido a ultranza las tesis que -bajo los respectivos rótulos de la comunidad nacional del trabajo y de la colaboración productiva - negaban la evidencia histórica y afirmaban la accidentalidad de la lucha de clases en los países industrializados con economía de mercado. La legislación ordinaria del sistema previgente cuidó de no agotar, cuantas veces actuaba su doble moral, los efectos positivos de las declaraciones programáticas con que las leyes fundamentales -integrantes de la Constitución abierta del fenecido régimen- reiteraron el compromiso del Estado con la garantía, en forma específica, del derecho al puesto de trabajo. La promesa se intentó reanimar, después de perecidos sus autores, al modo de una criatura póstuma de escuálida supervivencia. Una estabilidad que no perduró más ni menos que el tiempo preciso para probar el despropósito de su tardía exhumación. Conviene recordar que, al subrayarse esta extemporaneidad, cundió la expresión relativa al tiempo real de experiencia de una ley no aceptada.

La tentativa encarnada en la inoportuna legislación sobre las relaciones laborales provocó un descontento masivo. Si la transición democrática se preciaba de sinceridad histórica y dogmática, desalentaba el porvenir que, a través de una disposición trasnochada, reservaba el ordenamiento jurídico a un Derecho Social cuyas pretensiones de universalidad recababan la máxima apertura. Reclamaban la recepción preconstitucional de los instrumentos privativos del Derecho de Gentes que les informaba, y proscribían una solución que, como la nostálgicamente propuesta, fomentaba la confusión sobre el futuro sociopolítico y adecuaba -algo taimadamente- parte de su contenido a los paradigmas del anterior sistema que petrificaba y convertía en compromisos adquiridos. Lejos de confirmarse el acceso a un sistema cabal de libertades, subsistía -con la esperanza rota del soldado perdido- el difuso intento de alargar artificiosamente la vida de instituciones desautorizadas por el carácter y el impulso de la transición democrática que a la sazón daba comienzo.

Llamaba la atención, debido a la mala conciencia que la motivaba, la sobreprotección tardía de la estabilidad en el empleo que, de acudirse a una 
lectura evolutiva, habría adelantado -en clave ajena a la voluntad inmovilista del legislador- la cláusula transformadora y social con que, para liquidar las situaciones de desigualdad material, el texto constitucional invitaría, algo después, a producir una legislación de apoyo. Los sistemas democráticos contemporáneos confiaban la salvaguarda de la estabilidad individual del puesto de trabajo -antes de su sustitución, abierta la crisis económica, por la defensa colectiva de un volumen razonable de empleo- a un mecanismo de frenos y balanzas. Intervenían, de una parte, el poder de organización del empleador, cuyos excesos y/o precipitaciones le costaban caros si osaba atentar injustamente contra dicha estabilidad, y, de otra, el contrapeso que, frente a extralimitaciones de ese corte, significaban las reacciones de la autonomía y la autotutela sindicales.

Se explica la virulencia de las críticas a esa situación. La regeneración sociopolítica topaba con una regresión obcecada que, al desencadenar un aluvión de descalificaciones y censuras, obligó a dejar sin efecto buena parte de la temibilidad que la regulación entrañaba. La idea de reinstalar vestigios de la estructura autoritaria -propugnada por cuantos melancólicamente preparaban sus viajes a ninguna parte- se depuso ante la actitud de los poderes públicos que, impresionados por el parecer de la opinión, restauraron la confianza puesta en la exclusividad y el acierto de las opciones democráticas que, una vez elegidas, estaban en trance de cumplirse sin reservas ni obstáculos que las detuvieran.

\section{Aspectos notables del Derecho Social colectivo}

El sistema autoritario aborreció la huelga hasta el punto de que -vedando su invocación nominativa, excepción hecha de una incorrecta mención jurídico-penal- la declaró delito de lesa patria que, como variante de sedición impropia, se emboscaba en el impenetrable entretejido de los delitos contra la seguridad interior del Estado. Su despenalización -según la vestidura liberalizadora que desencantó a los analistas cuyo pensamiento de deseo ansiaba una evolución más progresiva y audaz- no redujo la huelga a una figura exenta de consecuencias negativas para sus promotores y/o agentes de especial intensidad. La evidencia del conflicto industrial -resignadamente aceptada por el sistema autoritario a la luz de las contradicciones internas de la sociedad pluralista y del derrumbe de la falsa ilusión cooperativa- abarcaba cuantas expresiones de disidencia colectiva sobrenadaban a la defensa de la unidad productiva al servicio de la patria. El confuso y difuso Derecho colectivo de la agonía autoritaria transigió con la terquedad histórica de la huelga y terminó acatando una expresión términológica que -proscrita hasta entonces- tenía el valor incipiente de empezar a llamar a las cosas por su nombre. La modernización postconciliar de la doctrina de la Iglesia católica ya sirvió de coartada, en algún caso notable de conmoción social, 
para invocar inútilmente la etiqueta que -como recurso y no como derecho subjetivo - asignaba el Derecho Sindical autoritario a esta forma de autotutela colectiva. Se recordó que la naturaleza programática de los textos de la legalidad fundamental -alegados y reinterpretados en el proceso judicial que suscitó la huelga- demoraba su eficacia preceptiva directa mientras el legislador ordinario -compelido por aquel adelanto- no lo tradujese en normas positivas e inmediatamente aplicables. Todo un acicate para la creatividad y los arrestos de que, en tal peripecia, pudo hacer gala la jurisdicción que conocía del conflicto y prefirió, no obstante, solución minimalista.

La obnubilación autoritaria rehusaba a la huelga la naturaleza jurídica -que, en sano Derecho de Gentes, le correspondía- de un derecho subjetivo o libertad pública de titularidad individual -integrante del patrimonio de cada trabajador- y colectivamente actuada por una comunidad de personas físicas que, propugnando el buen fin de la actividad de autotutela y eficazmente adheridos a ella, obligaba al empleador -so pena del fracaso de los objetivos huelguísticos- a consentir efectos coincidentes o razonablemente afines a los determinantes de la convocatoria. Peculiaridad divergente de las orientaciones de la Teoría General del Derecho, cuya enseñanza es la de que -so pena de rehusar al interés protegido la utilidad predicable de sus apetencias- la cualidad de sujeto de un derecho embebe el ejercicio de todas las facultades integrantes de su contenido esencial o núcleo invulnerable. Sobrepasadas las etapas de la huelga-libertad -hechura del contractualismo demoliberal- y de la huelga delito o ilícito contractual, seguida por corporativismo autoritario, era excesivo atribuirle, de buenas a primeras, el carácter de libertad pública o derecho subjetivo fundamental en que su reconocimiento residía. Al precio de esa concesión nominalista, la legislación autoritaria de urgencia -impactada por alguna decisión judicial que, para calificar las formas de participación en una famosa huelga de su tiempo, importó del Derecho Penal la causa colectiva de inculpabilidad consistente en la inexigibilidad de otra conducta- no tuvo reparo en obrar con pésima conciencia. Rechazó que la huelga mereciese el trato de un derecho ejercitable en el momento fijado por sus promotores y conforme a las conveniencias estratégicas de sus objetivos. La huelga devino un estado de necesidad -alternativa a la no exigibilidad de otra conducta- o un último recurso que sólo procedía si habían fracasado por completo las tentativas de resolver pacíficamente el conflicto plasmado en la interrupción concertada del trabajo. No era ésa, ni de lejos, la verdad de su enjundia técnico-jurídica.

El disfraz semántico a que apelaba la laxitud -rectius, cínica contumacia- autoritaria para tildar la huelga de baluarte defensivo remoto y rehusarle la cualidad, ofensiva y eficaz, de derecho subjetivo, encendió las objeciones de inconstitucionalidad anejas a tan caprichosa ocurrencia. Aun privada de los deseables controles de inconstitucionalidad, la entonces jurisdicción de trabajo cuidó, llegado el caso, de inaplicar los textos que denotaban ese mal y vulneraban un principio de irregresividad inherente a la fisonomía del 
cambio. Las dudas planteadas formaron parte de los desafíos que -gracias a los criterios histórico-evolutivos de interpretación accesibles en el período de transición democrática- se afrontaban con alguna fortuna. No hacía falta un uso alternativo cuyo empleo -manejando instrumentos mellados y acaso elegidos disparatadamente- dispensaban los auxilios hermeneúticos que, para sortear esas dificultades, tenían a mano los aplicadores de las normas de Derecho Social.

La fenomenología del poder colectivo -cuyos ejemplos se estrenaban y ganaban en peso específico- exhibía otro de los aspectos frecuentados por el interés general en difundir el rostro académico -es decir, ilustrado- y las expresiones polémicas del Derecho Sindical renaciente. Mientras primaron los rigores de la clandestinidad, los oponentes políticos del sistema establecido se localizaban y controlaban, sin dificultad, por la publicidad de su afán de testimonio y por la comisión de ciertas imprudencias desaconsejables para la prosperidad de su causa. Ello allanaba las tareas de su supervisión y/o vigilancia, otorgaba márgenes de permisividad y facilitaba la reducción o eliminación de sus actividades. Otro era el caso de los antagonistas sindicales que, como los pobladores de las catacumbas, actuaban con disfraces y en zonas de equívoca presencia, neutralizando la persecución del aparato autoritario. Impartían consignas y realizaban movimientos que, descolocando al mundo oficial, le convencían de la esterilidad de sus acciones antisindicales y -ante un enfrentamiento en que llevaba todas las de perder- le transmitían sensaciones de desasosiego y de derrota. Cualquier trabajador presente en el lugar de empleo constituía un sindicalista en potencia y presumiblemente provechoso, cuya dedicación comprometida se confundía con el desempeño de una ocupación profesional que era el objeto de una exigencia contractual y ocultaba el activismo solapado tras esa cobertura. Al compás de los ritmos de los hechos históricos, el sindicalismo clandestino agravó el mordiente de su agresividad. Sitió y asaltó los flancos más vulnerables del sistema político, denunciando el engaño de un sindicalismo oficial al que sólo restaba la salida de una retirada silenciosa que no quiso ni supo adoptar inteligentemente.

La subsistencia -perceptible, a medias, $y$, a medias, invisible- del poder colectivo sindical deshilachaba el frágil tejido del sistema y acreditaba un ímpetu que, acelerando el proceso de su consunción, le aquejó hasta el trance final de su perecimiento. Ello ocurría antes de abrirse el ciclo de la transición democrática y el debate sobre sus posibilidades y salidas. La falsa consistencia del sindicato vertical-que monopolizaba el régimen de las relaciones individuales de trabajo e ignoraba la existencia y las demandas de las relaciones colectivas- disimulaba lo recio y pujante de estas últimas. Se estaba ante un supuesto más de alzamiento del velo y también se advertía cómo el experimento asambleario -cuyas prácticas invadían la familia, el aprendizaje y la docencia, las comunidades sociales y el marco agostado del hecho religioso- incoaba el ensayo de democracia directa sindical que hallaría su 
espacio racionalizador en el texto central de las relaciones democráticas anunciado después como Estatuto de los Trabajadores.

Comenzados los trabajos preconstitucionales, el tema del reconocimiento y el carácter conferidos por el constituyente a los derechos sociales reclamaba un discurso sobre el particular, pues el zafiamente llamado borrador -al que un léxico pulcro y académico habría bautizado como texto de primera lectura- abundaba en imprecisiones y antinomias de fatigosa reducción. Objeciones que se aminoraron -gracias a la invención y complacencias del consenso- en momentos sucesivos, no exentos de incidentes, de la hechura de la carta política. Un texto que, ya en su fase polémica, predecía la elasticidad o aptitud pluralista que, gracias a una de sus excelencias capitales, le adjudicaba una fisonomía peculiar y -a la hora de aplicar las normas jurídicas cuya dureza había que ablandar- permitía obviar los requisitos de reforma de las constituciones rígidas. La elasticidad de nuevo signo no dependía de la comodidad del trámite reformador, sino de la libertad de interpretación -razonable, imaginativa y creadora- que, sin la complicación de ese aparato, procuraba los mismos o análogos efectos. La elasticidad de la ley fundamental adquiría un sentido distinto del que la separaba de las clásicas constituciones rígidas, pues, sin cambiar una tilde del tenor literal de los preceptos, cabía un uso variable de los conceptos jurídicos indeterminados que alojaban sus declaraciones, prohibiciones y/o mandatos. Algo dogmáticamente aproximado a las tesis maleables del Derecho Natural, la inmutabilidad de cuyas proposiciones básicas - harás el bien, evitarás el mal, no harás a terceras personas lo que detestas que a ti puedan hacerte- toleraba desenvolvimientos de contenido y pormenor adecuados a las circunstancias de las personas, del tiempo y del lugar.

Estos adelantos prefiguran una política judicial -no convenida ni coordinada de antemano, porque los postulados de la independencia lo impedían- resultante de la indivisibilidad del cúmulo de las nuevas realidades sociales y de los atractivos de una interpretación supraoriginalista que, desbordando la voluntad primitiva del legislador, acusa las diversidades que imponen los signos de los tiempos. Política judicial que destaca la aplicación independiente, a cargo de los jueces ordinarios, y las experiencias del Derecho Social en el período -indefinido y dúctil- de la transición democrática, considerada entonces única e insustituible, y entendida después, por algunos, como el primer capítulo de los cambios sustanciales que en el futuro pueden ocurrir.

Había ya irrumpido la doctrina extrafronteriza del uso alternativo del Derecho, que, sin elementos actualizados de interpretación, rehabilitaba -judicial y dogmáticamente- las normas del sector social del ex-ordenamiento jurídico corporativo fascista y -mediante atrevidas lecturas constitucionales- reconvertía, en el seno de una democracia recién erigida, las relaciones afectadas. La imposibilidad de que el legislador extranjero aumentase la velocidad de cambio necesaria para que, sin demasiada incertidumbre, 
los jueces aplicaran el nuevo Derecho derivado forzó esta toma de posición hermenéutica. Dado lo inaccesible de una interpretación evolutiva, ello supuso una postura rupturista con el ordenamiento obsoleto -que se consideró abolido en la medida conveniente- y el ejercicio de operaciones de reconocimiento de la eficacia preceptiva directa de los valores, principios y otras normas constitucionales. El elemento histórico-evolutivo de interpretación, ausente del medio jurídico en que se daba el uso alternativo extranjero, permitió que el autóctono Derecho Social se aprovechase de sus aportaciones elásticas al período de transición democrática. El principio de conservación de las normas jurídicas -en pro de la aplicación de las regulaciones útiles del sistema político extinto- quedó servido saludablemente y eliminó el horror al vacío que habría causado un pavoroso estado de inseguridad jurídica.

El sector del ordenamiento jurídico correspondiente al Derecho Social se ha beneficiado, más productivamente que cualquier otro, de que -en circunstancias propicias a la comisión de errores de bulto- se apelase al elemento histórico-evolutivo de interpretación sancionado por el Derecho constituido. Su acogida y cultivo muestran las ventajas de un espíritu móvil e inspirador de finalidades - propias y acomodadas a su tiempo- que fundamentalmente reflejaban la voluntad renovadora de las normas y, así las cosas, corregían o remodelaban la intención, ya distante y distinta, del legislador que las había puesto en la ciudad.

\section{Entorno, consecuencias y manifestaciones conflictivas de la crisis eco- nómica}

El tránsito de un sistema autoritario a unas relaciones de trabajo democráticas requería la revisión del orden público o Derecho necesario y de las funciones que sus normas cumplían en uno y otro marco. Máxime, cuando las ulteriores tendencias flexibilizadoras minaron los espacios tradicionalmente reservados a ese Derecho necesario y aceleraron los procesos desreguladores del Derecho Social.

El régimen autoritario -ávido de aplicar a las relaciones individuales de trabajo las disposiciones generales que paralizaban o empequeñecían la movilidad de la autonomía individual- suplantó la autonomía colectiva por el ejercicio de las competencias de control y tutela a cargo del Estado. Aunque la idea de orden público mantenía el nominalismo de su omnipresencia, la tónica erosiva del sindicalismo clandestino y su impacto en las relaciones y contactos de grupo conquistaban espacios de libertad que, muy a su pesar, el sistema establecido aceptaba de puertas adentro, aunque, disimulando el enojo del desgaste, continuase usando de un léxico plegado a su vanidad triunfalista y sus hábitos de propaganda. Antes de iniciarse la transición democrática, la fortaleza de la noción de orden público se hallaba devaluada y un tanto vacía de la solidez conceptual que era típica de su definición. Par- 
te, por concesiones a que el propio sistema se obligaba, aunque, para ocultar sus claudicaciones, recurriese a sofismas y arbitrios dialécticos empobrecidos. Parte, por el estado de cosas que caracterizaba a las relaciones de trabajo en virtud de las acciones sindicales veladas, de las presiones del contexto social, de los criterios de la opinión pública, del mimetismo de los modelos democráticos contemporáneos, y de las desautorizaciones y/o advertencias de los organismos internacionales. A partir de la ambientación constituyente, el orden público necesario deja de controlar el régimen de las relaciones de trabajo, aunque las exigencias - relativas al menos- de planificación democrática habiliten, especialmente en lo económico, formas de intervención oficial que, sin atentar contra los contenidos esenciales de las autonomías individual y colectiva, los modera -periférica y razonablemente- para no romper el equilibrio requerido por el concurso de otros valores constitucionales.

A la luz de esta señal premonitoria, la catalogación del empleo -un bien escaso, constitucionalmente protegido y exigente de un justo reparto- informa la redefinición del Derecho Social. Lo ratifican el advenimiento de la crisis -inteligentemente coasumida en los países industrializados con economía de mercado- y la inminente incorporación a la vastedad extrafronteriza de las relaciones económicas. La etiqueta de sociedad próspera que, para el crédito de sus éxitos y la prevención de sus fracasos, asistió al nacimiento del Estado de bienestar presuponía unas condiciones satisfactorias y optimistas, porque el diagnóstico de la economía general, lejos de coartar el ímpetu de su ejemplaridad, le transmitía sus estímulos óptimos. Justificaban ese optimismo, la variedad y el crecimiento de las ofertas de trabajo, la rapidez de su absorción por los demandantes de empleo, y las intuiciones de un clima económico que -con el automatismo de una regla cuasinatural-consumía, sin anomalías ni excedentes, los bienes y servicios dados al mercado. Este convencimiento disipaba, siquiera a medio plazo, los riesgos del temor de abandono o cambios repentinos en las preferencias adquisitivas de los consumidores. Se confirmaban los augurios sobre la estabilidad en el empleo y se mantenía la confianza en el modelo de relaciones contractuales por tiempo indefinido.

La aparición de la crisis económica, debida a las dificultades y/o discriminaciones de abastecimiento y al alza de los precios de las materias energéticas, ensombreció el panorama de una concurrencia que -con la holgura de unas reglas de juego observadas sin estridencias cainitas-actuaba en los ámbitos normalizados de la libertad de empresa. La convulsión causada por la crisis económica -que, como tantas especies de su índole, situaba ante la nebulosa de un futuro ignorado y temible- obligó a acudir, oscureciendo unas relaciones industriales exentas de fricciones demasiado álgidas, a las soluciones de reestructuración empresarial que expulsaron a muchos empleadores del mercado de libre concurrencia. Para paliar las sobredimensiones que erosionaban el núcleo intangible de la libertad de empresa, se propugnó 
la reducción del número de los contratos de trabajo a la cifra precisa para generar un volumen de bienes y/o servicios que, una vez transmitidos al mercado, se consumiesen por los demandantes sin discontinuidad ni acumulación residual de existencias. Había que cancelar los contratos cuya superfluidad constituía a los trabajadores en un estado escueto de disponibilidad y originaba la mora accipiendi de los empresarios que, incumpliendo, contra su voluntad, las cargas de procurar efectiva ocupación, alteraban la correlación -dictada por la naturaleza de las cosas- entre la dosis de fuerza de trabajo, aplicable a los bienes de producción transformados, y la cifra de bienes de consumo generados por su actividad profesional.

Se columbraba la magnitud de la contingencia de un desempleo estructural, que incidiría negativamente en la vida, el progreso y los hábitos de las sociedades infectadas por su virulencia y acostumbradas, con el tiempo, a explotar sus manifestaciones perversas. No siempre la clase empleadora -seducida por los cantos de sirena tecnológicos que, elogiando sus efectos mágicos, predecían el aumento de los beneficios y la minimización de los conflictos- mostraría el sincero propósito de atacar una plaga cuyos riesgos de corrosión de las comunidades afectadas lesionaban los intereses generales y enfrentaban a los poderes públicos con aspectos inéditos de la cuestión social.

Dos vías eran preferibles -entre los arbitrios al uso- para entregarse a la tarea de contener y acondicionar el desempleo. La primera ensayaba una nueva Política Social a cargo del Estado, deudor de prestaciones sustitutivas del salario que dejaban de percibir los desempleados, cuya seguridad económica, aunque módica, podía hacer de sus beneficiarios -animados por el doble juego y por los alicientes de la economía sumergida- los pobladores de una clase socialmente pasiva, técnicamente apática, hostil a reformarse profesionalmente -mediante las oportunidades de readaptación a su alcancey refractaria a reinsertarse en el mercado de trabajo. La segunda optaba por el método de reconversiones industriales que -camufladas bajo una rotulación publicitaria y engañosa- no fueron transformaciones de técnicas de sustitución y sí azotes atilanos que liquidaron, sin contemplaciones, numerosos ciclos productivos.

Las circunstancias que esculpieron la fisonomía de la sociedad industrial de la crisis fueron la contrafigura de las notas de la sociedad industrial de la prosperidad. He aquí el cómo y el porqué de este juicio. La cifra de los oferentes de empleo -temerosos de no encontrar fuerza de trabajo o profesionalización adecuada a las particularidades de las reconversiones industrialesdecreció de manera sensible y cautelosa. Exigían cualificaciones específicas de una mano de obra adaptable, sazonada y elástica, difíciles de satisfacer sin una readaptación profesional garantizada y solvente, por parte de los responsables de la formación, y una aceptación responsable de los trabajadores. La contratación de la fuerza de trabajo debía plegarse a las previsiones de un volumen de producción de bienes y servicios que, presumiblemente absorbi- 
bles por las predilecciones del consumo, descartaban los riesgos -disuasorios para el ejercicio lucrativo de la libertad de empresa- de las retenciones estériles y el aumento de las pérdidas. Los errores de cálculo fueron fatídicos en este orden de cosas, porque dispararon la estadística de las regulaciones de empleo, a base de los mal llamados despidos colectivos, y engrosaron los contingentes de desocupados. El recurso a la contratación temporal -cualesquiera que fueran su rotulación y variantes- se convirtió en el menor de los males posibles para reordenar el reclutamiento de los trabajadores dependientes. Constituyó una medida de fomento de empleo que animaba al empleador a contratar, curado del espanto de la sobredimensión y del temor a los perjuicios patrimoniales derivados de inmovilizar un exceso de plantilla frente a la reducción de las exigencias productivas que mostraba el desmoronamiento del mercado.

Olvidando que, según la filosofía del asombro, la guerra y la contradicción lo engendran todo, el pensamiento autoritario defendía que las colisiones entre el capital y el trabajo no provenían de los excesos de la plusvalía -que el primero de ambos factores productivos arrancaba al segundo- y sí de los desmerecimientos accidentales de la justicia social que, sin necesidad de transformar de raíz la sociedad, el poder público estaba en condiciones de restituir. El autoritarismo autóctono disentía de la negación paganizante del conflicto, pero hacía de la Política Social un instrumento de la producción que ignoraba el antropocentrismo de las relaciones de trabajo y las desligaba del respeto debido a la dignidad de la persona. Aceptó contenidos doctrinales del catolicismo social, aunque acogió también otras premisas de los modelos contemporáneos imitados, en cuyos espejos se miraba para fijar el contraste de su imagen. Ocultaba, a sabiendas, que el conflicto industrial - expresión inflamada de una lucha de clases que luego acertó a civilizarse y desistir del compromiso revolucionario que alentaba sus ilusiones de futuroresidía en la naturaleza de las cosas y, por mucha intencionalidad que exhibiese el voluntarismo del legislador, se atisbaba tras las tozudeces de un sistema empeñado en abolirlo por decreto. Hasta el punto de que -cuando la visibilidad del conflicto se impuso y contradijo, a todas luces, los dogmas ungidos de irrevocabilidad por el pensamiento autoritario- entraron en circulación las versiones propagandísticas de su realidad y provecho. Se incluyó, como embuste histórico de gran cabotaje, el diagnóstico de que esas manifestaciones conflictivas no emanaban de las viejas desigualdades sociales que el sistema autoritario estaba en disposición de enmendar, sino de las fértiles contradicciones de una prosperidad generada por el nuevo estilo de justicia social. Metodología que la propaganda oficial cuidó de imbuir sistemática y opresivamente.

Una constante del adoctrinamiento de dichos regímenes y de los paliativos de sus frustraciones consistió en dotarlos de un ropaje seudoliberal-que no empañaba el descaro y/o la rudeza de sus objetivos-y presentarlos como concesiones fundadas en la madurez y la fortuna conquistadas por los instru- 
mentos del sistema. Se inventaban versiones -rotundamente falsas- de una suerte de libertades paralelas de factura original y, sin el éxito deseado, se pretendía perpetuar la sumisión sicológica y moral de los trabajadores víctimas de este pensamiento.

La multiplicación de los acontecimientos conflictivos y su modo proteico de exteriorizarse en las postrimerías críticas del sistema autoritario abonaron el terreno para verificar, sin errores de bulto, lo que el antagonismo de las relaciones industriales, recrudecido como tal, significaba a la sazón. Había, pues el estado de cosas lo exigía, que delimitar un concepto -a saber, el de conflicto colectivo- que reclamaba la máxima solicitud. El sistema previgente sometió a un control administrativo de legalidad los conflictos colectivos económicos que, como su denominación indicaba, se promovían para denunciar la injusticia conmutativa contractual en las relaciones individuales de trabajo y mejorar las condiciones preexistentes. El control de la jurisdicción contencioso-administrativa -que se instituyó tardíamente- no alcanzaba a revisar las cuestiones de fondo ni a sanar las insuficiencias que cada uno de ellos -también llamados conflictos de intereses ante la inexistencia un derecho subjetivo que los perfeccionase- mostraban a través de su irrepetible planteamiento. De los conflictos colectivos jurídicos conocía -antes de emprenderse la transición democrática y merced a una fórmula heredada de la invención corporativa- la jurisdicción de trabajo.

Había que desentrañar dos cuestiones notables. Una, la concerniente a la judicialización de los conflictos colectivos económicos. Otra, la relativa a lo que -bajo la rúbrica común de conflicto colectivo jurídico- encerraban las variantes de aplicación e interpretación de su concepto.

El conflicto económico surgía a la manera como - para preservar la equivalencia objetiva de las prestaciones- el Derecho Civil se había ocupado de revisar los contratos de tracto sucesivo o dependientes del influjo de futuros acontecimientos. Albergaba una propuesta o tentativa de modificar las condiciones de trabajo que -a causa de las circunstancias económicas depresivas para la condición de los trabajadores o de las demasías del ejercicio del poder de organización del empleador- sufrían un desequilibrio global que, lesionando el interés anejo a todas y cada una de las relaciones individuales de servicio, reclamaba el rescate de una justicia conmutativa en trance de decrecimiento y dispersión. Desde la legalización del uso equitativo hasta el agotamiento del período constituyente, la mención de la equidad justificaba, con irrefutables argumentos, lo inexcusable de su ponderación judicial para dirimir conflictos económicos, pues de su naturaleza se infería -de modo comunicativo e inequívoco- la necesidad y posibilidad de que así fuese. Vigente el texto constitucional, la oferta de una efectiva tutela judicial dirigida a los portadores de intereses legítimos situaba -de pleno Derecho- el apoyo oficial a los conflictos económicos en el plano de conocimiento y dilucidación del Poder Judicial. Esto empero, tan meridiana conclusión no ha prevalecido en la práctica. Se han hurtado a la cobertura de un derecho fun- 
damental y a los ingredientes de su contenido esencial, la extensión e intensidad del conocimiento con que el Derecho constituido - de cuya rigurosa lectura al respecto no puede prescindirse- confiere a la jurisdicción esas atribuciones de control.

La distinción esmerada, entre los conflictos jurídicos de aplicación y los conflictos jurídicos de interpretación formaba parte de esta asignatura pendiente, junto al objetivo, definidor de los conflictos económicos, de reintegrar a cada relación individual de trabajo la dosis de conmutatividad que -rebajando su justicia contractual- le arrebataba el transcurso del tiempo. Es claro y resultante de las indagaciones históricas que, gracias a una espiritualización progresiva de la contratación, la generalidad de los contratos conmutativos admite una equivalencia subjetiva o equiutilidad individual de las prestaciones de las partes. Cada una de ellas iguala el valor del sacrificio que su obligación apareja, con la medida de la utilidad que la prestación de su cocontratante le depara. La falta o la pérdida sobrevenida de equivalencia objetiva de un contrato conmutativo no le priva -salvo en los casos especiales que el legislador considera constitutivos de una lesión grave- de la validez que el principio de autonomía de la voluntad le ha conferido. El contrato de trabajo es una excepción a este reflejo de la libertad contractual. Merma la autonomía individual, en beneficio del trabajador, y cuida de preservar una equivalencia objetiva que la autonomía colectiva del poder sindical y la acción de apoyo de los poderes públicos codefendieron ardorosamente para prestigiar la Política Social del Estado de Bienestar.

El conflicto colectivo económico pretendía novar-mediante las acciones de grupos representativos, de hecho o de Derecho, que conectaban con cada relación individual- la conmutatividad que, predicándose de la constitución de los contratos individuales de trabajo, se exponía a que el curso del tiempo achicase la justicia material y redujese la equivalencia objetiva de sus prestaciones. Se intentaba arrancar al empleador, con formas acremente reivindicativas, unas concesiones que -si, terminológicamente, parecían responder a lo que su nominación indicaba- eran parte de un supuesto resarcimiento testimonial. A saber, el de un daño que -bajo la anfibológica rotulación de deuda histórica e indefinidamente pendiente de liquidación- la clase trabajadora había sufrido en virtud de dos actitudes causales. Una de ellas, la desatención del Estado demoliberal que -al omitir la diligencia necesaria para adoptar, veraz y minuciosamente, un modelo social- hizo caso omiso de sus necesidades y evidencias. La otra residió en el ejercicio egocéntrico de las facultades de la libertad de empresa, consecuente con el papel que -empecatada mortalmente por su falta de cosmovisión- la filosofía liberal asignaba a la propiedad de los instrumentos y medios de producción, desconociendo la importancia de los mínimos de una Política Económica recomendable y canonizando las incursiones del capitalismo salvaje. Algo que se percibe en el universo de estos tiempos, cuyos agentes moralizadores -que, amén de escasear, parecen hablar en voz inaudible- no encuentran los cami- 
nos -que haberlos, los hay- para planificar y acometer la contrarrevolución o historia cargada de razón, frente a las posiciones -ofensivas y torpes- que, explotando su razón sin historia, gana el neoliberalismo en todos los confines de la Tierra.

La laguna de método para abordar los conflictos colectivos económicos era la ausencia de una norma previa que los regulase satisfactoriamente, pues lo irrepetible de las circunstancias de las personas, el tiempo y el lugar que enmarcaban sus antagonismos, pugnaban con una ordenación que -para tildarse de disciplina general y sistemática- debía fundarse, lo cual era imposible por hipótesis, en la sucesión de experiencias anteriores, sustancialmente coincidentes o afines, y expresivas de la vulneración o riesgo de lesión inmediata de un interés compartido por las comunidades o grupos de personas afectadas. Habría que preconstituir -mediante una legislación de caso único abundante en cualidades proféticas o dotes absolutas de adivinaciónla regulación equitativa que, siendo indispensable y apta para dirimir la controversia, agotase en ella su utilidad y aplicación. Salvo improbables excepciones, esa regulación no era transferible a la resolución de otros conflictos que podían suscitarse después. El tercero encargado de dilucidar un conflicto colectivo económico que no admite otros modos de composición, interviene como cuasilegislador que elabora la norma rectora del caso único pendiente, y como cuasijuzgador que -tras haberla fabricado- la traslada al supuesto pendiente de resolución.

La variante de los conflictos colectivos jurídicos implicaba -a causa del antagonismo creado por la disociación de los factores productivos cuya cooperación disminuía o cesaba desde el origen de la confrontación- la previgencia de una norma cuya aplicación se discutía por razones, más o menos complejas, de Derecho constituido. Bien porque, pese a la meridiana formulación del supuesto de hecho y de sus consecuencias, se obstaba frontalmente de adverso a la producción de esos efectos y se distorsionaba el ritmo regular de las relaciones jurídicas en juego. Bien porque los contendientes - compartiendo la lectura inteligible de la norma jurídica- alegaban razones de peso que la ponían en tela de juicio o neutralizaban su eficacia. Bien porque, rehuyendo un entendimiento inequívoco de su mensaje, concurrían interpretaciones encontradas que, según la traza del conflicto, era preciso armonizar, reducir o expulsar de raíz. El primer caso requería que, disipada la duda sobre el carácter colectivo del interés en juego, se declarase si -previo análisis de su posibilidad de subsunción- el supuesto de hecho de la norma colectiva, oficial o pactada, debía producir los efectos que preconizaba su texto. La negativa a que ello sucediese, podía emanar de una actitud antijurídica de desprecio al mandato del Derecho objetivo que la norma encarnaba o de la oposición de medios -defensas o excepciones- aptos para paralizar sus consecuencias. Las partes -que coaceptaban el entendimiento de la norma y no planteaban temas de interpretación- disentían de la producción de los efectos que anunciaban y alegaban los respectivos fundamentos de 
hecho y de Derecho en pro de sus respectivas pretensiones. No mediaba un discurso fatigoso sobre el alcance de una norma inequívocamente enunciada y absolutamente comprensible, pero se usaba de un razonamiento -más liviano y no menos enérgico-sobre el sí o el no del encaje del episodio litigioso en el tipo de su figura rectora. Ello exigía que la situación histórica del caso se adaptase, sin desajustes ni holguras, a la proposición constitutiva de la norma polémica y que no prosperase -en el sentido técnico de contraderecho o excepción de afín naturaleza- ninguna defensión bastante para contrarrestar la expectativa y/o producción de los resultados pretendidos.

Los conflictos jurídicos de interpretación diferían genéricamente de los conflictos de naturaleza económica y específicamente de los conflictos de aplicación recién considerados. La modificación de las condiciones de trabajo -que los primeros pretendían trasladar al clausulado de cada contrato individual- no contaba con el apoyo de una acción procesal que, deducida ante la jurisdicción competente, permitiese invocar la regulación previa de la ley y solicitar del juez ordinario una resolución sustitutiva de las voluntades de los interesados en pugna. El ordenamiento jurídico no se ocupaba de esta forma de revisión por cambio en la base del negocio. Más bien, se confiaba -sin ignorar lo ácido y árido de estas controversias- en la habilidad y el éxito de la autonomía de las partes conscientes de la necesidad de sanear sus relaciones productivas y evitar la ruina de una ruptura irreversible. No en vano, hay que insistir en ello, estaban condenadas a entenderse y el conflicto no podía abocar al fracaso de esta regla de oro tan difícil de mantener indemne. La decisión a cargo de un tercero -cuando no se usaba de un equivalente jurisdiccional menos complicado y más inductivo- ejemplificaba, como se ha advertido, un desdoblamiento de funciones asumidas por la misma persona física o jurídica. Se daba, en primer término, la actividad -semejante al papel de la legislación de caso único- del tercero que, atento a las sugerencias e intuiciones de la justicia material, inventaba -esto es, descubría- la norma jurídica inédita que, habiendo de aplicarse, se formulaba mediante la proposición oportuna. Venía después la acción cuasijurisdiccional que -partiendo de la regla obtenida para exhumar el verdadero rostro del conflicto económico y aclarar sus cuestiones polémicas- emitía el parecer o dictamen que aconsejaba la equidad inspiradora del Derecho objetivo del caso.

Toda esta doctrina se concilia con la posibilidad de judicialización que se ha indicado y que relativiza buena parte de su primitivo rigor.

La diferencia con los conflictos colectivos jurídicos residía en el asentimiento de las partes a la preexistencia y validez de la norma colectiva elegida para saldar la controversia, y en su desacuerdo sobre el significado y el alcance de las opciones interpretativas que admitía. Complejidad a la que se añadían los interrogantes del propio ejercicio hermenéutico. Hay normas colectivas que pertenecen al sector social del ordenamiento jurídico del Estado y que, sin perjuicio de las laboriosas tareas de su interpretación, se entien- 
den conforme a los criterios empleados para determinar el sentido de las reglas jurídicas de factura oficial. El ámbito de la autonomía colectiva comprende una cuasilegislación cuyo cumplido entendimiento requiere acudir a las pautas especiales de interpretación de los negocios jurídicos y manejar también las propias de las normas de Derecho objetivo. Ello explica la naturaleza mixta de las fuentes del Derecho de las relaciones colectivas de trabajo, cuya fisonomía manifiesta lo que hay en ellas de cuerpo de contrato y alma de ley.

\section{Eficiencia y perspectivas de las intervenciones jurisdiccionales}

La unidad de jurisdicción reflejaba, en los pagos del Derecho Procesal, el dogma juridico-político de la unidad de soberanía que el constituyente había convertido en presupuesto básico de la estructura del Poder Judicial y el servicio de la Administración de Justicia. Ello repercutió en el dato de que la llamada jurisdicción de trabajo en el sistema previgente pasó a denominarse orden social de la jurisdicción. No han sido pocos los interrogantes de interés que de este paso se han seguido.

Las pasiones catárticas de la transición democrática comenzaron censurando y restando valor -con acritud disuelta al cabo de algún tiempo- a las acciones de una jurisdicción cuya existencia e inventario de logros se silenció vergonzosamente en preámbulos legislativos de significación decisiva, como si un compromiso intencional de desmemoria obligara a testimonios que exaltaban la estulticia histórica y el desamor a la verdad. Se omitió, no por precipitación o inadvertencia, que -gracias al complemento unificador del recurso central de suplicación y no al de una casación decisoria hasta entonces de recursos minoritarios- se había afianzado la unidad de la mayor parte del sector social del ordenamiento jurídico y fijado un cuerpo de doctrina que acreditaba la solidez lograda por el acervo del Derecho Social desde sus orígenes hasta la apertura del sistema constitucional. Ni el mínimo recuerdo y gratitud merecieron los resultados unificadores que, a lo largo de más de seis lustros, esa auténtica jurisprudencia había acopiado en materia de conflictos colectivos. Si, alguna vez, se escribe el pasaje de la Historia del Derecho relativo a este punto, justo será que se designe, con nombres y apellidos, a las personas físicas capaces de tal resentimiento y responsables de semejante mezquindad.

La intuición de futuros problemas provocó posturas motivadas por la necesidad de armonizar la distribución territorial de la Administración de Justicia en el orden social, superpuesta a la de las respectivas Comunidades Autónomas, con la aparición de complementos interpretativos divergentes que emanasen de la aplicación unificadora de un Derecho Social del Estado indivisible y único. Se precisaba que -tras autonomizarse el espacio geográfico del recurso de suplicación que, parcelado a partir de su ámbito estatal, 
retuvo su denominación- las fórmulas unificadoras de doctrina, fruto de la casación centralizada, respondiesen a los objetivos de su establecimiento. A saber, procurasen un inventario, ya que no exhaustivo sí un tanto completo, de los desajustes y/o contradicciones que, vertical y/u horizontalmente, registraban la jurisprudencia superior y las jurisprudencias juveniles de los espacios judiciales autonómicos. Lo facilitaría la intervención -presumiblemente solícita- del Ministerio Fiscal, que, pese a todo, no ha logrado superar ese obstáculo.

Se deseaba cumplir los objetivos de una efectiva tutela judicial que asignaba al recurso supraunificador la tarea de garantizar la unidad y unicidad del sector social del ordenamiento jurídico del Estado. Designio que encontraba reparos de bulto. No resultaba fácil -antes bien, improbable y costosolocalizar, con mínimo rigor, las contradicciones merecedoras de denuncia, ni reaccionar con celeridad que, para normalizar el ritmo de recurso, no violase el derecho fundamental a la defensa de la parte interesada en invocarlas. Debía ponderarse la frecuencia estadística con que -atendiendo a los frentes en que su acción se desplegaba y a los medios personales y reales de que disponía- el Ministero Fiscal estaba en condiciones de recurrir cuantas veces procediera hacerlo. Había que conjurar los riesgos de que -si no mediaban las condiciones indicadas- las normas de Derecho Social, generadas por el poder central, se interpretasen e integrasen con aportaciones complementarias que -como parte del cuerpo de doctrina fijada en los recursos de suplicación y/o en las variantes de la casación común y excepcional- causaban una petrificación irremediable. Variedad de criterios que, a falta de una selección acertada y una impugnación eficaz, terminarían canonizando la autonomización del Derecho del Estado. El espíritu y la finalidad de una norma jurídica, dictada por el legislador central, no pueden ser los mismos en dos o más espacios regionales donde las respectivas realidades sociales revelan la emergencia -peculiar y tangible- de sendos espíritus móviles. Abonan interpretaciones que -irreductibles en todo o en parte- se solidifican.

Un sistema de recursos acorde, en un principio, con la legalidad fundamental del ordenamiento jurídico -porque presumiblemente aseguraba el cuánto de efectividad predicable de la protección judicial de los derechos subjetivos e intereses legítimos- podía adolecer, a la larga, de una inconstitucionalidad sobrevenida peculiar y conceptualmente distinta de la que, así llamada, sólo es una inadecuación de normas previgentes a la incoación de la democracia constitucional. Si bien la presunción -inicial y asistida de toda cordura- de constitucionalidad alcanzaba, de entrada, a muchas de las normas sociales promulgadas por la legislación central, su favor se expone a decaer ante las experiencias de una aplicación que, lejos de confirmar la seguridad jurídica de la aspiración nomofiláctica, no unificaba el Derecho Social del Estado ni mitigaba las disparidades que engendraban esas contradicciones. Un futuro modelo de recurso -apto para enmendar tales inconvenientes y al que quizás convenga la etiqueta de recurso de control de diver- 
gencias interpretativas- puede cumplir satisfactoriamente -si, alguna vez, se certifica el óbito del recurso de casación tradicional- los objetivos dificultados por unos riesgos de inconstitucionalidad sobrevenida más probables que los que, con resignación, son de prever.

\section{Fenomenología específica del sindicalismo}

Comprometía lo suyo el afrontar -con cosmovidencia y prudente diagnóstico- las novedades de la fenomenología sindical, ya que, además de responder al cumplimiento de una exigencia derivada del Derecho de Gentes, el sindicato rehabilitado por el constituyente devenía un agente social que, privilegiado como poder de hecho significativo, fue investido de funciones inéditas. Su privilegio implicaba, en primer término, que el sindicato de estructura clásica -basado en las categorías representativas y en el ejercicio de la democracia delegada- coexistiera con otras variantes de morfología sindical. Aumentaban la popularidad y el entusiasmo por una democracia directa que, con ingredientes emocionales muy activos, acogió -para eliminar los lastres que coartaban su efectividad- la bondad de los elementos racionalizadores de sus maneras de operar.

El nuevo sindicato nacía de los episodios -desconcertantes y agravadosde una crisis económica que, para arrostrar un cúmulo de dificultades y adoptar actitudes acordes con la agresividad de los cambios, demandaba compromisos muy duros y sacrificios impensables. Debía recobrar las expresiones colectivas e individuales que, impulsadas por el esfuerzo de transformación, alcanzasen excelentes niveles de progreso social. El sindicato constitucionalizado no acertaba -quizás para evitar a su clientela, sedienta de resultados y conquistas, una impresión de complacencia con el empresariado y/o los poderes públicos- o se resistía a digerir un postulado entonces coasumido por el sindicalismo occidental contemporáneo. La dimisión de la autosuficiencia económica y el ingreso en un universo democrático de relaciones industriales coincidía, para el infortunio de su causa, con un trance de crisis cuya disciplina requería adoptar medidas austeras y abstenerse de populismos triunfalistas. Todas las economías industrializadas de mercado ya estaban entrenadas en el ejercicio de estas prácticas o virtudes sociales que los sindicatos constitucionalizados no se decidieron a hacer suyas con convencimiento y energía. Quizás, por ello mismo, así fueron las cosas.

El sindicato no servía su oficio en solitario, sino que -a cambio de su posición privilegiada y afín a la de las iglesias nacionales en los modelos de confesionalidad del Estado- asumía, por mandato del constituyente, la función social de contribuir. Lo que obligaba a preguntarse por el sentido de la contribución y las características y cualidad de los sujetos -públicos y/o privados- con los que su desempeño debía compartirse. La contribución sindical se extendía -aunque tan optimistas perspectivas no se hayan confirmado- 
a la promoción y defensa de objetivos propios, un concepto jurídico indeterminado cuya formulación ambiciosa iba mucho más lejos de las adquisiciones meramente sociales que se recobraban. Perseguía también aquellas metas que, según las circunstancias del tiempo y del lugar, la libérrima opción del sindicato declaraba preferibles e insertaba en las bases de su acción protectora. Ocupaban espacios vacíos o habitados por personas físicas y/o sociedades parciales que servían insuficientemente a intereses requeridos de atenciones más edificantes y continuas. La apropiación de nuevos objetivos respondía, entre otras, a las consignas de sustitución o suplencia de la actividad de unos partidos políticos que -tras haberse ganado, a conciencia, los recelos del electorado y usado, hasta el hartazgo, del blindaje que les facilitaba la inexigencia de mandato imperativo- sólo eran partidos de cuadros, renuentes a unas tentaciones de conmoción y contacto sociales que los sindicatos podían, si aceptaban el reto, intentar con visos de fortuna.

\section{Relativización de las acciones de tutela social}

La realidad legislativa del momento no podía eludir la convicción -gobernada por el voluntarismo político- de que los ecos de la máxima «siempre más, nunca bastante» se esfumaban en un régimen público de Seguridad Social que, entre luces y sombras, sepultaba el principio de irregresividad de las adquisiciones sociales y presuponía que, en voz baja, la carta política era ya bautizada como el texto constitucional de la crisis, con las reservas inherentes a tan pesimista etiqueta. $\mathrm{Al}$ esplendor de la máxima de los reformadores sociales del norte de Europa, sucedía el santo y seña de acomodar -reajustándolas con dureza y ausencia de misericordia- las excelencias del Estado de Bienestar al cuadro de rebajas de la inmersión en la crisis económica. Los poderes públicos -enfrentados al síndrome de desinversión y abandono de los empleadores que, ante el panorama de degradación del empleo, dimitían de su atrevimiento y arrogancia en los ámbitos de libre competencia- denunciaban, con explicable alarma, el crecimiento de las contingencias provocadas por la reducción de las ofertas de trabajo.

Había que atribuir a la protección del desempleo galopante un reducto de atención urgente en la lista de las situaciones de necesidad que históricamente se le anteponían. Era inaplazable dotar a los procesos productivos de oportunidades que aliviasen los inconvenientes y los efectos disuasorios de la fuga de los titulares de la libertad de empresa que desertaban del mercado de libre concurrencia, debido a la depauperación de sus elementos materiales y a la quiebra de un instinto competitivo lastimado por falta de estímulos. Los poderes públicos, lejos de ejercer sus potestades de control sobre dicho ejercicio, insistían en una actitud de apoyo que prolongaba la intensidad y la vehemencia -obra del pasado del Estado social y democrático de Derechocon que se subrayaba la cooperación de los empleadores al cumplimiento de 
las cargas sociales que afianzaban el nivel de bienestar. El contenido esencial o núcleo invulnerable de la seguridad que el constituyente reconocía como derecho fundamental, dejaba fuera de sus opciones de tutela -pese a las tentativas hermenéuticas amparadas en el elemento histórico-evolutivo de interpretación- la variante de la seguridad colectiva. Supondría ésta la adopción de las medidas tendentes a prevenir o indemnizar los daños que, con frecuencia y habitualidad probadas, asediaban a la normalidad de las actividades humanas y enturbiaban los episodios de la vida de relación.

El modelo de Seguridad Social vigente al iniciarse la transición democrática representó una herencia que -salvo detalles de menor enjundia- no estaba hipotecada por el decisionismo político general o por alguna de sus condiciones esenciales. Superaba, sin dificultad, la prueba del mecanismo de depuración establecido para concluir que, globalmente apreciada, no acusaba la inadecuación constitucional designada bajo el rótulo impropio -fruto de la fenomenología de aquel cambio- de inconstitucionalidad sobrevenida. Una contradicción en los términos que -alterando la normalidad del orden de las cosas- situaba cronológicamente la norma constitucional de control a seguido de la legalidad previgente que se controlaba. Esta figura exótica era ventajosa y paliaba equitativamente el endurecimiento de la reconversión democrática de las normas del sistema autoritario, que, al seguirse aplicando, evitaban los inconvenientes del miedo al vacío. Mediaban diferencias notables entre el entendimiento que la garantía constitucional -relativa al régimen público de Seguridad Social-adquiría en la era de la prosperidad - ambientadora del esplendor del Estado social y democrático de Derecho y de su Política Social-y el impuesto por las vicisitudes de la crisis económi$c a$. Una crisis que incidía en las relaciones individuales de trabajo -cuya traza de progreso decaía vertiginosamente- y no menos en el plano de las relaciones colectivas. Éstas ponían a prueba la madurez de unos sindicatos atrapados entre la condena a entenderse con el capital y a desdibujar los perfiles de una conflictividad creativa, y la urgencia -debida a motivaciones de prestigio frente a sus afiliados y devotos- de mantener enhiesta la figura y no claudicar en tan escabrosa encrucijada. Una crisis que propagaba sus cambios a las peripecias del sistema de la Seguridad Social. El imperativo del salvamento social determinó -con consecuencias que fueron más lejos de lo exigido por los sacrificios tendentes a mitigar sus agresiones- las lecturas e interpretaciones antagónicas que, en las sucesivas épocas de prosperidad y de crisis, dictaron los cánones garantizadores o reglas de oro de la protección colectiva que se cuestionaba.

Las tesis de la Seguridad Social de la prosperidad difundían, como dogma de fe, que el régimen público sólo era el marco del portento de las soluciones con que los poderes públicos garantizaban el principio de irregresividad de las adquisiciones sociales. Así constaba el pago de la deuda histórica legada al Estado social y democrático de Derecho por un Estado demoliberal que había errado al diseñar el edificio que su modelo -el de la 
clase burguesa dominante- quería ocupar a perpetuidad. Era el marco de unas particularidades selectivas que amparaban las contingencias preferibles en función de la urgencia inherente a la satisfacción de las situaciones de necesidad apreciadas. La preferencia - peculiar de los derechos cuya plenitud y respeto no se concebían sin una financiación adecuada- se atendía con una generosa asignación de los recursos sociales destinados a ello, sin ignorar que la suficiencia de las prestaciones -exigida por el Derecho Social constituido- era indisociable de la limitación de esos recursos, por grande que fuese su disponibilidad, y difería de la reparación íntegra del daño que utilizaba el Derecho de la responsabilidad civil. La preferencia obligaba a posponer el cuidado de las contingencias que, aunque oteadas en el horizonte de la necesidad de protección, no eran inaplazables. Mantener el régimen público significaba entonces que el aumento de los niveles de bienestar - puestos en negro sobre blanco por el legislador que se hacía cargo de las propuestas y/o adquisiciones sindicales- sólo podía detenerse, a lo sumo y algo así como marcando el paso, en circunstancias de excepción que lo justificasen. Los poderes públicos seguían obligados a responder a las reivindicaciones sindicales que, en nombre de un valor cultural afianzado, reclamaban la reanudación del proceso de adquisición interrumpido. El principio de irregresividad no concebía el mantenimiento como un estado de supervivencia oficial de la gestión pública, vacío de la sustancia que la completaba paso a paso. Invocaba un compromiso consistente en la prohibición de interrumpir la defensa de las expectativas en curso de consolidarse y los beneficios sociales ya perfectos. Algo que parecía inmutablemente natural y que luego sería rechazado como un pecado de leso neoliberalismo. De ahí, la traslación de la idea -en parte sindical y en parte técnico-jurídica- de derecho adquirido al ámbito de las relaciones colectivas y las equivocidades a que ha dado lugar. No menos, de las operaciones de caza y captura, que, para terminar con ella, arruinaron su sustantividad ante el Derecho y liquidaron las existencias de su rico inventario.

Distinto era el alcance que el Derecho Social de la crisis asignaba a la noción de aquel mantenimiento, erigido en un concepto jurídico indeterminado con significación contradictoria de la que antaño se le atribuía. La comprensión minimalista -que estimuló el afán de arrinconar, con pretextos y medias verdades, los avances del Estado de Bienestar- se transfirió a la legislación y a la lectura de la legalidad fundamental manejada para incentivar -valga la paradoja- el progreso galopante de las regresiones. Se sostuvo que ese mantener se refería a la mejora del contenido de las prestaciones sociales del régimen público, sino que solamente reiteraba su carácter de deudor de éstas y excluía las fórmulas de privatización absoluta. El compromiso no pasaba de ahí y dejaba en una zona deslucida y opaca -expuesta a escalofriantes augurios, cual el de generalizar una Seguridad Social asistencialcuanto afectase al crecimiento de sus objetivos. Prevalecía el compromiso de continuar una Política Social vinculada a unas posibilidades -más o menos 
escasas- dependientes del voluntarismo de los poderes públicos y de no abandonar la zona protectora en que estaban obligados a permanecer. Sin cuestionarse la atribución de esas obligaciones, importaban más la dosis de beneficio efectivo y lo impreciso de la satisfacción correspondiente a los intereses legítimos que, necesitados de tutela, debían convertirse en derechos subjetivos. La defensa a ultranza del principio de irregresividad y las esperanzas depositadas en su arrojo quedaron al margen de un decisionismo cuyas providencias reductoras no fueron atacadas por los sindicatos con la debida intransigencia. Interesaría analizar cómo y hasta dónde los imperativos éticos de los sindicatos y sus predilecciones estratégicas se conciliaron para no combatir con denuedo el principio del fin de la fuerza social de las relaciones de trabajo.

La Seguridad Social de la prosperidad se atuvo a unas pautas posibilistas y graduales. Reclamaban que se ponderase -sin restricciones arbitrarias ni prodigalidades demagógicas- la cantidad y calidad de los recursos que, derivados de las fuentes elegidas por el legislador, amparaban las contingencias protegibles. El gradualismo -expresión muy cara a la semántica del Derecho Social y compartida por otros de sus problemas destacables- traslucía la propensión a beneficiar a todos los ciudadanos de la tutela del Estado de Bienestar, con pausas distintas de la congelación o el paso lento, y a racionalizar un equilibrio equitativo entre el juego de las fuentes de financiación y la naturaleza y/o posición de los grupos sociales o sociedades parciales afectados. El objetivo de la tutela del régimen público era una sociedad pluralista e indemne que, para resarcir los daños sufridos por sus comunidades e individuos, contase con remedios idóneos. La propagación de esos beneficios a toda la ciudadanía -como anunciaban los constituyentes imbuidos del espíritu social-culminaría la ejecución del «cuán largo me lo fiais» que subyacía a las promesas optimistas del Estado de Bienestar.

La extensión de sus beneficios a todos los ciudadanos es, para la Seguridad Social de la crisis, algo más constreñido y consonante con el espíritu de sobriedad que predican sus profetas de encargo. Se dicen conmovidos por el cambio, desconcertados por las mudanzas del estado de cosas ocurrido y prestos a sacrificarse para ofrecer soluciones más modestas que, en vista de sus lamentaciones, preserven la sustancia de un Estado de Bienestar que -a la luz de su pensamiento demolitorio y de las acciones consiguientes- pierde mucho de lo que le es consustancial. Alguna confiscación presupuestaria de las pensiones públicas -de que no disintió ninguno de los partidos políticos con representación parlamentaria, pese a su compromiso explícito de hacerlo eficazmente- es una muestra escandalosa de esos experimentos de tala o reducción. Apelando, como es usual, a la solidaridad, se elogian las ventajas que depara la elección de una Seguridad Social asistencial -no vedada por el constituyente al decisionismo político del legislador ordinarioy capaz de perfeccionar los adelantos de su mermado posibilismo. La preferencia por la solución asistencial puede reducir la Seguridad Social contribu- 
tiva a proporciones ínfimas y, lo que es alarmante, ponerla en trance de exterminio o detrimento máximo.

La Seguridad Social de la prosperidad concibió la suficiencia de las prestaciones económicas al modo de un dato que, ante la tasa de los recursos disponibles y la selección de las contingencias protegidas, difería -cualitativa y cuantitativamente- de la reparación íntegra del daño asociado a la situación de necesidad que privaba de bienes debidos al sujeto. Su resarcimiento abarcaría - para restituir las cosas a su primitivo estado- el valor de la pérdida causada por la contingencia acaecida y de los beneficios que había impedido conseguir. La suficiencia de las prestaciones públicas -contemplada objetivamente y a tenor de la seguridad jurídica- trataba de aminorar una distancia. A saber, la existente entre la indemnización cabal del daño sufrido y la dosis de atención patrimonial que, con los medios a su alcance, destinaban los poderes públicos a colmar el espacio vacío dejado por esa carencia. Se entendían conceptualmente persuasivas -guardando las apariencias y adaptando sus soluciones a la naturaleza que el sistema adquiría y a la confusión dogmática que se engendraba- las prestaciones que una determinación cuasitridentina del poder público estimaba bastantes para declarar extinguida la situación de necesidad pendiente de satisfacción. Algo afín a un ejercicio de planificación atípica, cuyo voluntarismo rompía con el esmero técnico-jurídico de las instituciones del Estado de Bienestar y de los sistemas de Seguridad Social inspirados en ellas. Faltaba la libertad -moral e intelectual- indispensable para que el decisionismo político de los legisladores -distendido por el margen de libertad otorgado y el cuánto de responsabilidad contraído- se atuviese a las cargas de la ética político-legislativa que pesaban sobre sus acciones. También para que los intérpretes -constitucionales u ordinarios- se abstuviesen de osadías hermenéuticas cuya irreversibilidad terminaba obligando a un acto de fe en sus ejercicios de interpretación.

Las intuiciones y sondeos de la Seguridad Social de la prosperidad no atisbaron el dato - convertido después en un axioma de la Política Social- de que el trabajo estaba llamado a ser un bien escaso y repartible con criterios de solidaridad y justicia distributiva. No se llegó a prever algo reñido con la fertilidad de los factores convergentes en las relaciones de trabajo de los países industrializados con economía de mercado. No era de temer el advenimiento de un estado de cosas cuya probabilidad escapaba a la perspicacia de las predicciones más sutiles. Los observadores de la evolución de la Seguridad Social de la crisis económica elevaron la magnitud del desempleo -ante los episodios de reestructuración causados por las dificultades de aprovisionamiento o de sustitución de materias energéticas- a la categoría de una contingencia de primer orden, que, además de su novedad cualitativa, daba cuenta de la conmoción social de sus apariciones. De ahí, la transición a una Política Social empequeñecida y dependiente de las circunstancias que, según esas transformaciones, orientaban erráticamente sus cambios de rumbo. 
Las prestaciones sociales -estimadas suficientes por un acto voluntarista de nominación- dejaban de serlo a causa de su escasez cuantitativa para reparar los daños anejos a la situación de necesidad. Las prestaciones complementarias -que eran libres en el caso de suficiencia material de las prestaciones principales públicas-devenían suplementarias y forzosas para compensar la insuficiencia sustantiva que los auxilios oficiales no enmendaban. La libertad forzada convertía en sarcástico el tenor de la cláusula por la que los poderes públicos decían mantener un régimen público de Seguridad Social cuya indigencia no escapaba a las críticas de su fisonomía transformada.

\section{Redefiniciones del derecho a la libertad de empresa}

Ha sido y, sigue siendo, pese a las apariencias, una verdad -secreto a voces- de la Historia reciente la tesis de que la Política Social europea o, para discurrir con pulcritud, la coordinación -aun por aquello de ser lo mejor enemigo de lo bueno- de las Políticas Sociales nacionales ostentaba el carácter de pariente pobre de las políticas comunitarias. La Comunidad Económica Europea no asumió la prevalencia de los valores sociales de la Comunidad Europea del Carbón y del Acero y, por ello, el problema de reservar a la Política Social un espacio habitable abrió la controversia que obligó a reemplazar los propósitos de una Política Social unitaria -ordenada sistemáticamente en las instituciones de las comunidades económicas- por la armonización de las Políticas Sociales de cada uno de los países miembros. La ida en pos de la tierra prometida de la Europa Social invitaba a examinar los pormenores que el ingreso en la Europa comunitaria aportaba al concepto de libertad de empresa.

El reconocimiento constitucional de este derecho se plasmó en una fórmula que -a la luz de las ventajas e inconvenientes del consenso- toleraba una doble lectura fundada en la elasticidad del valor superior del pluralismo político. Valor que autorizaba desarrollos entre sí divergentes de la norma constitucional que amplificaban, pero siempre ajustados a la legalidad fundamental e inteligibles conforme a sus principios y/o preceptos. El primero de ambos entendimientos defendía que el único modelo económico admisible era el de la economía de mercado -en cuyo seno la libertad de empresa se desenvolvía- y que, ante lo rotundo y excluyente de esta tesis, holgaban las interpretaciones paralelas o afines a los modelos planificadores del cuasimarxismo en boga a la sazón. Otra lectura más sensible planteaba dos alternativas a la fórmula elástica del pluralismo político, vidriando acaso el principio ontológico de no contradicción y su lema de que una cosa no puede ser y dejar de ser al mismo tiempo. La primera variante prejuzgaba el juego clásico de la economía de mercado y, con ella, el ejercicio de la libertad de empresa en los países industrializados que la practicaban. La segunda pros- 
cribía dicha libertad si, como base de la interpretación, se militarizaban los episodios económicos y se elegían los caminos de la planificación absoluta a cargo del Estado.

La protección de la productividad por los poderes públicos dependía de una u otra de dichas actitudes. Las exigencias de la economía general eran, para la primera, una consecuencia de la movilidad que caracterizaba a las operaciones de ese signo, puesto que su ejercicio afianzaba el entretejido del mercado de libre competencia. La referencia a la planificación se entendería restrictivamente, pues, sólo en circunstancias de excepción, reajustaba las demasías de una libertad sujeta a restricciones. En la segunda hipótesis, los imperativos de la economía general segregaban un concepto jurídico indeterminado que el decisionismo político podía actualizar, ya que no a su ilimitado albedrío, sí en virtud de criterios adecuados a las particularidades de las personas, del tiempo y del lugar. La tutela de la productividad no procedía entonces de las iniciativas protectoras de los poderes públicos, sino que les forzaba a respetar las directrices de una economía ya planificada. Modelo que, al concretar las previsiones del constituyente, la legislación podía adoptar por obra y gracia de un pluralismo político que apoyaba la razonable libertad de su elección.

Lo preceptivo de acomodar este mensaje a los textos internacionales ratificados por España, determinaba que -producido el acceso a la Europa comunitaria- esa elasticidad se disipase. Sobrevivía el análisis de la libertad de empresa en una clave que -descartado el prejuicio de la planificación anticipada- no atentase contra el contenido esencial o círculo intangible del derecho fundamental afectado. A saber, la libertad de establecimiento y la libre circulación de capitales que habían ganado carta de naturaleza en el espacio europeo. La interdicción de una planificación autoritaria de la libertad de empresa acotaba la zona de maniobras y llevaba a preguntarse sobre la mejora de su calidad en el campo de los derechos reconocidos constitucionalmente.

Cuestión que se enfoca a la luz del principio de primacía del Derecho comunitario. Hay una interdicción de que las normas del Derecho de los Estados miembros -incluidas las componentes de la legalidad constitucional interior- contradigan las pertenecientes al Derecho Fundamental o derivado de las comunidades europeas, que prevalece sobre aquéllas. Debe destacarse algo más sobre la comprensión de este principio. La fisonomía de una institución regulada por el Derecho de cualquiera de los Estados miembros requiere adjudicarle -declarativamente, por hipótesis, y no constitutivamente, por el voluntarismo causal del poder público- la misma naturaleza jurídica que, según los postulados innatos de un orden natural europeo, le confieren las normas del Derecho comunitario. La libertad de iniciativa económica y las variantes de su propagación -confiadas a la autorregulación peculiar del contenido esencial de este derecho- pertenecen al acervo comunitario de derechos fundamentales. El principio de primacía del Derecho comunitario 
prohíbe que la legislación material o vertical de los Estados miembros dinamite la esencia de la libertad de empresa y, desvirtuando la identidad del derecho fundamental que entraña desde la perspectiva europea, le asigne una posición sistemática y un tratamiento jurídico que degradan y/o deterioran su totalidad. Se está en presencia de un derecho público subjetivo impuesto a la voluntad del constituyente e incompatible con complacencias que desfiguren su verdadero rostro. Algo que inequívocamente luce en el horizonte, constitutivamente histórico, de la razón práctica. Si el constituyente atribuye a dicha libertad una naturaleza de proporciones medias o inferior calidad, rebajando la conveniente a sus condiciones innatas, la deficiencia es abolida en virtud del principio de primacía del Derecho Comunitario -que veda esas reducciones sustanciales- y reemplazada por el óptimo trato a que la aplicación de aquél conduce. La libertad de empresa en el marco de una economía de mercado -positivizada como una libertad de proporciones mediasasciende a la categoría de derecho fundamental en el ordenamiento jurídico estatal que le rehusaba esa titulación. No cabe otorgarle un tratamiento más tenue o menos agresivo que el preceptuado por el ordenamiento jurídico supraestatal que obliga a lo contrario. Se defiende, en suma, la elevación de la libertad de iniciativa económica a derecho fundamental de cada Estado miembro que, en el marco europeo de las relaciones industriales, la juzga inseparable de la libertad general de las personas físicas y jurídicas que ejercitan las facultades y asumen las cargas de las funciones sociales que están a su cargo.

La atribución de este carácter -objeto de un debate que demanda serenidad y reflexión- invitaba a diseñar la libertad de empresa como un derechofacultad cuyas manifestaciones de poder se encaminaban a obtener un beneficio económico y a superar los riesgos ordinarios que lo entorpeciesen. También justificaba el calificarle de derecho-función, porque la propiedad obliga en virtud de las funciones sociales del dominio -sobre los instrumentos y medios de producción- que, sin esperar a las futuras concreciones de los legisladores ordinarios, predice la regla en blanco que el constituyente ha tenido a bien adelantar. Lo primero implicaba el ejercicio de cuantas facultades -relativas a la selección, destino e inversión del capital, régimen de las relaciones individuales y colectivas de trabajo, y técnicas de racionalización del proceso productivo- aguardaban respuestas conexas con las conminaciones de una crisis económica cuya gama de temores y vacilaciones se adueñaba del espacio social europeo.

La función social de la libertad de empresa coartaba el contenido de un derecho de disposición que incluía la facultad de abandonar, sin trabas, el mercado de libre competencia. Los titulares de esa libertad no habían de afrontar riesgos incómodos o peligrosos, porque su concepción de la economía de la prosperidad no les imponía el deber -moral y social- de sufrir, por tiempo indefinido, los quebrantos patrimoniales de un endeudamiento improductivo. La dependencia de estas cargas conservaba activos y sustraía 
a los inconvenientes de la territorialidad ambulatoria -luego atizada por la globalización - los ciclos de producción cuyo arraigo geográfico aconsejaba una terapia moderada que preservase su continuidad. Había que aminorar las anomalías de las relaciones de trabajo y reducir -conteniendo la virulencia de su impacto- la velocidad de crucero de la crisis económica, para evitar la irradiación de las reconversiones salvajes. La expansión cualificada de las ofertas de trabajo, completada con los efectos positivos de la readaptación profesional de los demandantes, sanearía los aspectos morbosos de la fenomenología de la crisis. Se desaceleraba, en los casos más álgidos, el proceso maligno de degradación del empleo que, por inercia o simpatía, mostraba alarmantes síntomas de empobrecimiento.

\section{Tendencia a la igualación en el progreso}

A estas reflexiones se sumaba un componente inseparable, fruto del interés en aclarar -llamando a las cosas por su nombre y no rindiéndose a las tentaciones de un disfraz desvahído- la alentadora cláusula de equiparación o igualación en el progreso que encabezaba la lista dispositiva de la Política Social europea. Ello movió -con resultado estéril y acompañado de algunas mezquindades que el pudor impide pormenorizar- a instar la interpretación propuesta en la primera de las cuestiones prejudiciales que, tras su ingreso en las Comunidades, planteó el Reino de España ante el orden jurisdiccional comunitario. Se recababa un parecer sobre el que los jueces ordinarios -promotores de dicho incidente- rotulaban de cláusula transformadora similar a la constitucionalizado en algunos Derechos nacionales de la Europa económica. Para ratificar -con ingenuidad que los hechos han corroborado- el alcance atribuido a ese pasaje y fomentar el avance de la interpretación propugnada, se suplicó un pronunciamiento que, como complemento jurisprudencial, delimitara el entendimiento de la claúsula en el orbe geográfico de las Comunidades. El grueso de las alegaciones de la cuestión prejudicial denunciaba ciertas medidas regresivas de signo social que el legislador estatal había adoptado sin observar tres condiciones exigidas por la naturaleza de las cosas y consistentes en la conclusión de un previo acuerdo con los sindicatos representativos, en la ejecución gradual que aligerase el perjuicio causado por tales medidas, y en la fijación de indemnizaciones suficientes para compensar el daño anejo a la pérdida del derecho o el interés legítimo de que se priva al grupo social o a la persona. Se denunciaba la reversibilidad -pecado de lesa Seguridad Social-de unas prevenciones reñidas con el espíritu de progreso de las cláusulas cuya interpretación se debatía. Se pedía la declaración de que, al conducirse así, la Política Social gubernamental vulneraba la consigna transformadora de igualación en el progreso, entendida como clave de los propósitos de cambio que acampaban en esos precedentes e incluso utilizaban algún elemento aprovechable del pensamiento jurídico marxis- 
ta. Consigna que, de incorporarse al pensamiento social europeo, refrendaba la idea -muy cara a dicho cuerpo de doctrina- de que el Derecho no sólo está en circulación para pacificar los conflictos entre las partes afectadas por la colisión de sus intereses, sino también para igualar las condiciones sociales $\mathrm{y}$, acelerando el ritmo de su bienestar, transformar la fisonomía de las modernas sociedades. Pese a lo escrupuloso y reflexivo de los términos en que la cuestión prejudicial se dedujo, su destino no corrió la mejor de las suertes. Soportó el tratamiento de una técnica reductora o cirugía de jibarización -que la jurisdicción comunitaria decidió aplicarle- y también la enemiga con que la distinguieron algunas instancias políticas del Estado soberano autor de la medida enjuiciada. Primó la conclusión -desalentadora y poco edificante- de que el órgano judicial comunitario no debía conocer de aspectos que -como el concerniente al principio de irreversibilidad de las adquisiciones sociales, clásico, capital y confirmado por los aleccionamientos de la Historia- habían caído en desgracia de las normas comunitarias invocadas para defender su subsistencia.

Una vez más, se acreditaba la atonía con que, pese a las menciones platónicas de la Europa social, las instituciones comunitarias equiparaban sus reclamaciones a las del pariente provinciano e incómodo con quien molesta relacionarse y/o comprometerse demasiado. La densidad de la petición de una respuesta inequívoca a los temas generales que se consultaban pudo influir en la obsesión simplificadora de la resolución recaída.

Tampoco estaban fuera de la inquietud europeizante las reflexiones provocadas por la aplicación del Derecho Comunitario a las experiencias de crisis de empresa. Había que reinterpretar, por vía de actualización, las normas del Derecho autoritario que no asoció el tratamiento de la crisis al ejercicio del poder de organización del empleador que intentaba una operación de salvamento. Ahora procedía acomodar a las exigencias del mercado el volumen de producción -castigado por las reconversiones industriales y las vicisitudes de la oferta y la demanda- y acreditar la causa colectiva de extinción de las relaciones contractuales a través de los despidos plurales, bautizados después con el nombre impropio de despidos colectivos. La intervención de las representaciones sindicales y del poder administrativo laboral -reflejo anacrónico de la injerencia de los poderes públicos que controlaban y/o restringían, en el transcurso de la crisis, las prerrogativas empresariales de organización- se calificó de regulación más favorable. Gracias a una conversión hermenéutica, el novedoso papel de esos agentes - de hecho y de Derechorobustecía la igualdad y evitaba la indefensión social de los trabajadores despedidos por causas tecnológicas o económicas. Se moralizaba y socializaba el tufo neoliberal que, para facilitar los despidos plurales, tenía puesto a punto el ordenamiento jurídico comunitario. Un Derecho estatal, restrictivo y pendiente de amparar los intereses egocéntricos del régimen paternalista autoritario, devenía un Derecho actualizado, democráticamente generoso y abierto a la tutela de los intereses generales de las Comunidades. El Derecho 
Comunitario europeo -encadenado por una de sus normas jurídicas en blanco-facilitaba el juego de acciones de apoyo innominadas e imprevistas.

Conviene asimismo aludir al problema -que se abordó más tarde- creado por el Programa de Convergencia que, junto a otros aspectos, incidía en un tema tópico de las vicisitudes del Derecho Social. A saber, la determinación del alcance de la injerencia del Estado en la regulación de las condiciones de trabajo y la definición de un principio de subsidiariedad que difería del concepto inherente a su rotulación en la era demoliberal. Había que erigir, para ello, un principio de autonomía fundado en la presunción tácita de dos proposiciones. Conforme a la primera, nadie mejor que los sujetos individuales y colectivos inmersos en el círculo de los problemas apreciados, conocían los antecedentes, las motivaciones y los hechos históricos de que derivaban aquéllos. Dominaban exhaustivamente el supuesto de hecho de las decisiones o pautas relativas a las situaciones cuyo examen condicionaba el amparo de sus intereses. La otra presunción anunciaba que, aunque el poder público estaba en condiciones de proveer a dichas exigencias, no podía aportar el toque de individualización que aseguraba sus efectos óptimos. Los agentes sociales, que advertían de primera mano los términos en que los problemas adquirían la cualidad de tales, se obligaban a adoptar las soluciones coherentes con su conocimiento inmediato y certero del estado de cosas, y con el uso de la diligencia exigible para despejar sus interrogantes.

\section{Ensanchamiento de los espacios sindicales}

La condición -privilegiadamente constitucional y sometida a cargas de cierta importancia- que la legalidad fundamental otorgaba a las organizaciones sindicales, se tornaba exigente hasta el punto de que la libertad sindical tuvo que abrirse paso como el resultado de un esfuerzo reinterpretativo. Ello implicaba el derecho de los sindicatos a elegir y dar cabida en sus programas, además de los objetos de su atención tradicional, a cuantas hipótesis de deficiencia social considerasen dignas de una mejora a cargo de su acción cooperativa. La atribución de la naturaleza de derecho fundamental partió de un razonamiento imprescindible para perfeccionar un reconocimiento involuntariamente incompleto. La situación contemplada bajo la estricta rúbrica de los derechos fundamentales y libertades públicas no agotaba los contenidos propios de la creciente libertad del sindicato.

Había que apelar a un discurso que, con un mínimo de imaginación, satisficiese un objetivo doble, a saber, la definición omnicomprensiva de la libertad sindical y su reconocimiento como derecho fundamental adornado de los atributos que -más allá de la mera eficacia- realzaban su efectividad. La oferta innominada de apoyo que los poderes públicos cursaban a los sindicatos les invitaba a utilizar -diríase que con indiscreta frecuencia- la institución del Estado social y democrático de Derecho que representaba el pro- 
ceso judicial. El sindicato invadía la vasta tierra llana de cuantos, yendo en pos de la efectiva tutela judicial de sus derechos subjetivos e intereses legítimos, accedían a los beneficios del derecho fundamental que esa protección innovaba. El proceso judicial estaba a disposición del sindicato, porque se habían disipado los prejuicios emocionales y la terquedad rupturista que -hasta su renuncia a la revolución- el programa revolucionario sindical mantuvo frente al talante antisocial del Estado de Derecho liberal burgués. Libre de estos reparos, se recordaba al sindicato la diversidad enriquecedora de sus intereses legítimos y se le imputaba una deuda de cooperación sumada a las iniciativas que podía emprender en solitario. El deber de contribuir, en coalición o en desacuerdo con otras organizaciones, admitía -desde una perspectiva sincera y socialmente productiva- un uso sindical del proceso del que antaño el sindicato disentía por varias razones. Unas eran emocionales e instintivas, otras aducían los dogmas fundamentalistas que negaba la salvación social fuera de los cauces brindados por el sindicato, y otras, en fin, brotaban de un rechazo difuso del proceso judicial, a causa de las experiencias negativas que éste había supuesto para el triunfo de las reivindicaciones sindicales. El Estado demoliberal contempló estas reacciones desde una perspectiva general, a la que sólo fue excepción la crisis de una conciencia social minoritaria -tan testimonial como inútil- enfrentada al decisionismo pedestre de la burguesía. De ahí, la confusión intencional de los esfuerzos y luchas sindicales con supuestas tentativas de alteración del orden público que era obligado combatir. La represión de las acciones sindicales contó con la complicidad de un Poder Judicial enojado por el hecho de su aparición y resuelto a defender el derecho de propiedad privada y las manifestaciones expansivas de su ejercicio en el mercado libre de bienes y servicios. Se reprimía el movimiento que, augurando la fulminación violenta del Estado burgués, pretendía acercarse a la meta del fin de la historia, que sucedería a los cambios de la dictadura del proletariado, y liquidar la dominación del sistema demoliberal, cuyo aplastamiento controlado entraba de lleno en el cuerpo de las premoniciones sindicales. Los textos sagrados del sindicalismo acusaban a los jueces de ser -junto a otros poderes de hecho y de Derecho, como los aristócratas, los banqueros, los militares y los eclesiásticoslos enemigos naturales de la clase trabajadora y los opositores más hostiles al prevalecimiento de sus aspiraciones colectivas.

Los sindicatos percibían -nebulosa e intuitivamente- que su acceso al ámbito físico de la soberanía del Estado no emanaba de una concesión que graciosamente les adjudicaba un espacio habitable, sino de un acuerdo que tácitamente combinaba los ingredientes de control y de apoyo -necesarios para la regularidad de aquella recepción- sin privarles de la condición de sujetos institucionales soberanos. Carecían de la base geográfica sustituida por las condiciones en que su recepción se producía. La idea de poder sindical y la denominación de la autonomía colectiva ejemplificaban una confrontación civilizada o condena a entenderse con los poderes públicos, fuera 
de cualquier postura de sometimiento a las decisiones de la jurisdicción. El reciente desarrollo normativo del proceso facilitó a los sindicatos fórmulas de legitimación general, sindicalización de acciones y represión judicial de conductas antisindicales que, sin provocar el rotundo rechazo de sus beneficiarios, no suscitaron un entusiasmo desmedido. La estadística judicial da fe de la parquedad con que el sindicato - no siempre consciente de la sinceridad y utilidad de esas ofertas- ha aprovechado el apoyo de sus formulaciones. El desarrollo protector ha judicializado los conflictos colectivos -claramente los de naturaleza jurídica e implícitamente los de orden económico, que la jurisdicción no acaba de atraer a su conocimiento- y se ha extendido a los conflictos impropios, cuya judicialización es obra del decisionismo político de la legislación procesal delegada.

Interesaría conocer las estadísticas de cómo -salvaguardando su pretensión de autonomía- los sindicatos han utilizado los equivalentes jurisdiccionales o sustitutivos procesales, y compartido la oferta de apoyo que -fuera de cualquier amago de control-subyace a la declaración del derecho a la efectiva tutela judicial de sus derechos subjetivos e intereses legítimos. La fuerza vinculante -que es la fuerza de ley de las normas del ordenamiento extraestatal- de la negociación colectiva proclama que el constituyente llama, en auxilio de los beneficiarios de sus cláusulas convencionales, a un Poder Judicial dispuesto a injerirse en unas relaciones sindicales cuya normalidad no mediatiza ni altera. Aporta un ingrediente de templanza jurídica que el antagonismo y la crudeza de las contiendas de esa índole no siempre garantizan ni logran imponer a las voluntades de los empleadores y sus asociaciones.

Conviene volver sobre la fenomenología de la huelga que animaba el proteísmo del Derecho Social colectivo en su evolución general y en sus particularidades autóctonas. Las alergias del sistema autoritario previgente brotaban de un trío de supuestas agresiones que, a juicio de sus críticos, lesionaban su prosperidad y prestigio. Procedía la una de los movimientos declarados, a la sazón, separatistas y desintegradores de la unidad nacional. Residía la otra en la acción de los partidos políticos, a cuya voracidad doméstica y desinterés para con la cosa pública se achacaban las desventuras que asolaban a la sociedad. La última consistía en la insaciable reiteración de las huelgas, reputadas fatídicas para la buena marcha de la economía y la defensa de los intereses de los trabajadores.

La interferencia del régimen autoritario imprimió a la evolución de la huelga un ritmo conceptual y cronológicamente distinto del que, desde los albores del Estado demoliberal hasta entonces, revelaba el examen histórico de sus cambios. La huelga-delito señalaba una primera etapa en que, como excepción cualificada a la neutralidad exigible, el legislador tipificó episódicamente la coalición punible e incluyó la libertad de comercio y de empresa en la lista de bienes objeto de la tutela jurídico-penal. La figura siguiente de la huelga-libertad redimió al Estado demoliberal de las responsabilidades 
del pecado venial consistente - a la usanza de entonces- en una acción de apoyo a la libertad de empresa y no fue más allá de un incumplimiento masivo que, sin consecuencias punitivas, resaltaba la eficacia disuasoria de los males derivados de tal actitud. Si los trabajadores se sumaban a la huelga, porque eran libres de desatender sus obligaciones de disponibilidad y asistencia al trabajo, los empresarios podían invocar la antijuricidad de cada incumplimiento personal y extinguir los contratos individuales por medio del despido. La huelga-derecho perfeccionaba un ideal del Derecho de Gentes de las relaciones de trabajo y confería al sindicato el poder colectivo de constituir -elegidos la oportunidad y el momento estratégicos de emplear ese medio de presión institucionalizada- a los grupos de trabajadores, cuya voluntad sustituían, en una situación convenida que, además de otros efectos secundarios, autorizaba a omitir las prestaciones específicas del deber profesional de trabajar. La atribución subjetiva del derecho adquirido e ingresado temporalmente en el patrimonio de cada titular constituía una causa de justificación que -a semejanza del modelo jurídico-penal- excluía la ilicitud de la conducta de inasistencia al trabajo e impedía cancelar los contratos amparados por esta eximente. Así se explicaban la titularidad individual del derecho de huelga y su oponibilidad, por vía de excepción, frente a la determinación empresarial de despedir. La función compulsiva de la huelga exigía que, aceptada esa titularidad individual, su cualidad de derecho en pie de guerra se realizase colectivamente, porque, sin el impacto de sus conminaciones, fracasaba el mecanismo de presión institucionalizada que igualaba materialmente a los sujetos del conflicto. Sus objetivos de autotutela no se agotaban con la puesta en situación que suponía su disponibilidad de arranque. Hacía falta que el elemento de coactividad-que, so pena de fracaso, debe asistir a toda acción de huelga- interviniese eficazmente o que, al menos, se mantuviese la dosis de temor de necesario y suficiente influjo en la actitud del empresario ante el riesgo creado por la adopción de la máxima medida de conflicto.

Las vicisitudes autóctonas de la huelga ganaron en complejidad y artificio. Implantado el sistema autoritario, la recriminalización de la huelga como delito de lesa patria nada tenía que ver, pese a su reingreso en la órbita del Derecho Penal, con las rudimentarias acciones de apoyo embebidas -hacía tanto tiempo- en la rancia política persecutoria del delito de coalición. No se trataba de amparar, a su efímera usanza, el interés económico de la libertad de comercio e industria, sino de sancionar -con la altivez del pensamiento autoritario- la violación de un deber público de solicitud y diligencia, que lesionaba la unidad al servicio de la patria en que la idea de producción se resumía. La obsesión de aportar una imagen amable y condescender con los disfraces engañosos de la libertad, llevó, más tarde, a una despenalización de la huelga que no eliminó sus repercusiones negativas en la vida de las relaciones de trabajo. Agonizando el sistema autoritario y tras alguna decisión judicial utilizable, se recurrió al arbitrio -doctrinalmente inédito y 
debido al empeño en conciliar la continuidad autocrática con la falsa imagen de las libertades subsistentes- de la huelga-recurso. Sin categoría de derecho, la figura de nueva creación se asemejaba a una eximente de responsabilidad colectiva que -imitando el estado de necesidad o la inexigibilidad de otra conducta- inmunizaba a los contratos de trabajo contra los acuerdos de despido. Pese a la represión exasperada de estos movimientos, la aplicación de la ingeniosa teoría gradualista permitió que -aquilatando la voluntariedad individual de los intervenientes- la jurisdicción atenuase, conforme a la equidad, el alcance de la máxima sanción de despido y recortase las extinciones masivas de contratos por la participación material de los trabajadores en huelgas ilegales.

El constituyente concibió la huelga como un derecho fundamental cuya ordenación legislativa y autorregulación sindical parecían, a primera vista, incompatibles y, eran, no obstante, impecablemente adecuados a la legalidad fundamental. No tanto por la maleabilidad interpretativa con que el valor superior del pluralismo político autorizaba a reaccionar, cuanto por obra y gracia de la conjugación gramatical en presente de subjuntivo -deslizado incontroladamente y de rondón en el texto definitivo- del verbo regular elegido al efecto. Esa conjugación impedía denunciar la inconstitucionalidad por omisión del desarrollo legislativo del derecho de huelga, si constaba inequívocamente la preferencia del poder público -que se abstenía de legislar- por los mecanismos autorreguladores. Queda en pie la duda -creciente y cré́ble- de si la ordenación inmediatamente preconstitucional del hecho huelguístico, acuciada por motivos de credibilidad democrática, no ha sido abolida por el engrandecimiento de las realidades sociales subsiguientes a una regulación urgente cuya supervivencia se cuestiona con razones de peso. No han faltado pretextos para desistir de una regulación completa, porque la coyuntura no coincidía con las exigencias centrales del derecho fundamental. Las tentativas obedecieron a las razones de orden público que lo requerían contingentemente, pero nunca se remataron para analizar, en condiciones de serenidad intelectual, las exigencias y los problemas técnico-jurídicos suscitados por el modelo constitucional y por su adaptación al ejercicio colectivo de la potestad de autotutela. El más reciente ensayo corrió la suerte de un templado proyecto gubernamental que, iniciado el trámite parlamentario, se convirtió en un furibundo instrumento de las acciones sindicales que -administrando y adueñándose de las vicisitudes de la huelga- fulminaba la cordura del texto inicial. El frenesí del aparato partidario y el sentido de responsabilidad del poder público entraron en conflicto. La alarma social -quizás menos intensa de lo exigido por las circunstancias- que despertó la tramitación del proyecto, fue la causa eficiente de una decisión cuya interioridad histórica no se ha desvelado por completo. Dícese que, cuando el texto aprobado por el Congreso se hallaba en la Cámara Alta pendiente de su devolución, se acordó -gracias a las presiones de la comunidad empresarial y a la conclusión de un pacto inconfesa- 
do con el Poder Ejecutivo- la disolución de las Cortes Generales. Se acudió a una vía desproporcionada, si se quiere, pero inevitable para sepultar la masa de riesgos que, oteados de cerca, impedían que el proyecto fuera lo que sus autores habían desechado de raíz. Ejemplo de cómo, de buenas a primeras, el decisionismo político retiró su etiqueta de urgencia a una iniciativa que, después de declararse inaplazable, se ha olvidado y pospuesto por tiempo indefinido. Ese estado de cosas dio la oportunidad -harto justificada y académica- de ensayar una revisión crítica del tratamiento de la huelga y de la información comparatista sobre sus imágenes y expresiones históricas.

\section{Recapitulación constitucional}

Con cuatro lustros de atraso sobre las iniciativas europeas, la expansión democrática de las relaciones industriales se abrió a los adelantos de la flexibilidad y al uso ponderado de la desregulación. Surgió la oportunidad de debatir si el porvenir universal del Derecho de las relaciones de trabajo no aconsejaba su transformación -a la usanza del modelo histórico de las antiguas recepciones- en un Derecho Social de principios para una reforma social de preceptos. La rapidez con que se sucedían las construcciones -teóricas y prácticas- del Derecho Social y se disciplinaban sus instituciones, inducían a las propuestas de este estilo. Denotaban una especial velocidad de tránsito de la dogmática a la Historia del Derecho, con las dificultades y -también hay que decirlo- los alicientes de creatividad interpretativa que estas circunstancias engendraban.

Consideraciones que movieron la puesta en común sobre el Derecho constitucional del Trabajo en España, con participación de juristas españoles y brasileños que, representando a las instituciones más notables, acreditaron la utilidad y el valioso balance de su encuentro.

Circulaba también la inquietud relativa a las parcelaciones o rupturas que, en algunas circunstancias de su aplicación, podían afectar al Derecho Social emanado de la competencia exclusiva del Estado. Las nuevas perspectivas y posibilidades trajeron a capítulo cuanto entonces podía referirse a los temas de la unidad y la coherencia o indivisibilidad del sector social del ordenamiento jurídico.

Ante las repercusiones del Tratado de Amsterdam en la versión consolidada del Tratado de Roma, la idea de las luces y sombras de la Europa Social se manejó de nuevo para mostrar la necesidad -obstada por sistema e indefinidamente- de un tránsito que, con paciencia inagotable, aguardaba su turno. A saber, el salto de la timorata e impropiamente llamada Política Social europea a un espacio deontológico donde la protección reconocida fortificase la naturaleza -que aquellos textos avalaban- de un derecho fundamental a los beneficios de la Seguridad Social. 
Todo este cuerpo reflexivo remozaba consideraciones que -ante las evidencias de los signos de los tiempos- se habían adelantado en su momento y que, gracias al curso de los acontecimientos, aconsejaban precisiones complementarias y matices.

\section{Hacia la recepción e instalación del hecho globalizador}

Las comprobaciones asociadas al fenómeno de la mundialización y de sus inquietantes capítulos llevaron -tras un examen esmerado de su incidencia en las relaciones industriales- a conclusiones veraces y abundantes en cierto pesimismo. Toda la historia de esas relaciones -absorbida por la atención prestada al ritmo y las mudanzas de un conflicto endémico- condicionaba su sobrevivencia. El descubrimiento y la notoriedad del dogma histórico-social del antagonismo entre los agentes de la producción justificaron el diagnóstico - marcado por el cuerpo de doctrina y las inquietudes de la lucha de clases- favorable a la constancia del conflicto industrial. Algo que la oscurividencia del Estado liberal se empeñó en ignorar o, a lo sumo, tildó de castigo civil impuesto por una coyuntura históricamente explicable y llamado a remitir sin tardanza. A tan voluntarista y voluntariosa muestra de ignorancia, sucedió el dictamen -modelo de agudeza intelectual- de las llamadas luego por el neotomismo minorías de choque proféticas. Grupos que, tras tomar cuenta y razón de los cambios sociales debidos a las tensiones del conflicto, predecían la necesidad de atajar, con soluciones ajenas a la política de lamentaciones, las incertidumbres derivadas de su expansión irreprimible. La tozudez y contundencia de los hechos determinaron que al diagnóstico selecto del conflicto - ciegamente ignorado por el Estado-ordenamiento y el Estado comunidad- sucediese la conciencia fatalista de su comprobación y la renuncia a cualquier acto de medicina social bueno para encauzarle. La fuerza de las cosas obligaba a reconocer su magnitud y convivencia con una fenomenología convulsiva. El Estado demoliberal y los poseedores de los instrumentos y medios de producción se enfrentaban a los agentes sindicales que -rehusando, al verse vencidos de antemano, cualquier solución de compromiso con el sistema burgués cuyo juego de ventaja les arrinconaba- elegían la senda revolucionaria para liquidar la opresión y los desmanes imputados a las instituciones democráticas. El Estado de Derecho liberal burgués -empavorecido y cauteloso - tomaba nota de la entrada en liza de la nueva clase, pero acataba escrupulosamente las reglas de neutralidad de su filosofía política. Ni de lejos se plegaba a aceptar las responsabilidades de su contribución al bienestar general -confesando el relieve social de las aportaciones de la fuerza de trabajo- y del respeto a la dignidad de cuantas personas físicas poblaban esa creciente sociedad parcial de su interior. De ahí, su esterilidad deplorable para adivinar y administrar las peripecias de un conflicto plagado de riesgos que se multiplicaron con el tiempo. 
Fue posterior la abolición artificiosa del conflicto que los sistemas autoritarios suplantaron por el establecimiento de una comunidad nacional -de capital y trabajo- y la conversión de los procesos productivos en unidades de colaboración cuya idílica perspectiva -animadora de algunas adquisiciones positivas de Política Social- acabó truncada por los sucesos políticos internacionales y por la combatividad infatigable del sindicalismo clandestino. La racionalización o distensión del conflicto fue parte de la decisiva operación emprendida por el Estado social y democrático de Derecho que -a través de aproximaciones y tanteos- dejaba fuera de cuestión la inconmovilidad del sistema democrático y arrancaba a las organizaciones sindicales de los países industrializados de economía de mercado sus promesas de renuncia a la revolución. El sistema insertaba al sindicato en el marco postbélico de unas relaciones industriales civilizadas y le confería un activismo social audaz y perceptible. Posición que, animada por la favorable coyuntura económica de la sociedad occidental sumida en los encantos del mercado libre, fomentó un estilo sindicalista de gestión, cuyas demandas cuantitativas se sustanciaban generosamente, y orilló las de un sindicalismo cualitativo de reivindicación que, preso de ese triunfalismo, no se esforzó en poner a punto algunas de sus asignaturas pendientes. De ahí que, como reacción avalada por el tiempo, la transfiguración morfológica del conflicto revelase la extensión protectora del Derecho Social al ejercicio de los derechos constitucionales en el lugar de empleo y a las nuevas formas de acción sindical que, trasladando el conflicto a las unidades productivas, iba en pos de los objetivos cualitativos marginados por el sindicalismo de gestión. Se alzaba una barrera frente a la ansiedad competitiva de los empleadores que multiplicaban las técnicas de racionalización aconsejadas para sobrevivir en el mercado y poner a prueba las variantes maléficas de la plusvalía. Aceleraban, sin tasa ni piedad, los ritmos de trabajo y convertían a los trabajadores en inconscientes cómplices de su explotación tecnificada. Desnaturalizaban el deber profesional de trabajar que, de una obligación de medios o de simple actividad, pasaban a serlo de fines o de resultado. El asentamiento de la democracia industrial salvó, si no todas, sí algunas de las contradicciones que había engendrado esa dinámica.

La moderación del conflicto acontece cuando la crisis económica -que atravesará las fases sucesivas de aparición inopinada, coexistencia tolerable e inmersión absoluta- obliga a reemplazar la dureza de la confrontación por actitudes de colaboración que, so pena de entenderse o perecer, refluyen en distintos aspectos. Los sindicatos, que habían desistido de la revolución, aceptan, como males menores, gravosas renuncias al principio de irregresividad, a la subsistencia del concepto de derechos adquiridos y afirmados históricamente, y a la sustitución de la defensa de la estabilidad del puesto de trabajo por la protección colectiva de los niveles de empleo expuestos a una degradación enorme. La indisponibilidad o el encarecimiento de las materias energéticas crean dificultades que reducen las ventajas cuantitativas de los trabajadores a cambio de concesiones en la política de empleo, de mejora de 
las condiciones de seguridad e higiene, y de aumento de las garantías del ejercicio de las libertades sindicales. Enfatizan la carga empresarial de acelerar los procesos de reconversión industrial que aseguran la continuación y la presencia en el mercado de bienes y servicios, para bien de los consumidores, y en el mercado de ofertas de trabajo, para desacelerar la destrucción del empleo. La ineficacia del deber de paz lleva a sustituirle por obligaciones individuales de productividad con que la parte normativa de la negociación colectiva suple el perjuicio causado por la impunidad de que -rompiendo la conmutatividad de los convenios- los sindicatos se servían para soslayarle. Esta dulcificación del conflicto - cuyas apariencias de provisionalidad sugerían la vuelta a la normalidad de antaño- puso en camino del despeñadero neoliberal. Ocurrió así porque, sin posibilidades de un control eficaz, se generalizó el ejercicio abusivo y, por lo mismo, irracional de unos derechos flexiblemente destinados a conjurar una crisis que, ante esta sorpresa, se desboca en derroteros laberínticos. El cuasimonopolio -dominante y selectivode las ofertas de empleo constituye, a partir de ahí, la clave del perjuicio irrogado a los derechos de los trabajadores.

Un paso más y se intuía la disolución del conflicto que predecía la aventura facilitada por el ejercicio multidireccional de la libertad de establecimiento y el derecho a la libre circulación de capitales. Los empleadores exceden y emigran de los ámbitos territoriales de localización del conflicto $\mathrm{y}$, movidos por los alicientes del poder multinacional, privan a la clase sindical de opciones tangibles de oposición y de presencia en el campo de juego que antisocialmente abandonan. Penetran en espacios geográficos donde la simplicidad de la estructura social, lo difuso de la conciencia de la dignidad personal, el efecto invasor de las novedades tecnológicas y la ausencia de sensibilidades culturales al respecto, favorecen la construcción de un escenario idóneo para herir de muerte el ya debilitado, aunque tenaz, influjo del conflicto en las relaciones industriales. Tras la disolución, cabe hablar de la civilización del conflicto, no en cuanto enriquecimiento -que, a su tiempo, fue positivo y aleccionador- de las normas de Derecho Social, sino del remate de la desregulación. Toda una tendencia a suprimir la ya empequeñecida injerencia del Estado y a engrandecer el poder contractual del empleador, cuya dominación enfrentaba a los trabajadores individuales en posiciones de conflicto impropio. La autonomía sindical dejaba de pesar en la fijación de unas condiciones de trabajo que nacían de la contratación individual y que -al perder su carácter de conquistas debidas a las acciones meritorias de los sindicatos- les retiraban uno de los rasgos que, más y mejor, habían cooperado a su prestigio.

Al cabo de estas regresiones en la edificación de la parte más sensible y amplia de un orden jurídico justo, el modelo sinóptico del Derecho Social objetivo quedaba ensombrecido y, a veces, eclipsado por la intensidad de las agresiones económicas. Restaba poco de la estructura de una relación individual de trabajo que, gracias a las aportaciones de la Teoría General del 
Derecho y el Derecho Civil, llevaba camino de un enriquecimiento dogmático favorecido por las adquisiciones justas y no por las rebajas de los derechos de los trabajadores. El Derecho colectivo volvía a sindicalizar los objetivos de gestión -dificultando y entenebreciendo los de reivindicación- que no se ejercitaban ya porque el Estado y los empleadores se adelantasen a satisfacerlos, sino porque estos mismos sujetos frenaban las propuestas sindicales de mejorar lo módico de aquellos resultados. El Derecho de la Seguridad Social sufría el castigo de las torpes coartadas con que -asociándose a las alabanzas de las recetas neoliberales- la doctrina oficial de los Estados soberanos acumulaba impedimentos y pretextos para yugular las intenciones de retorno al Estado de Bienestar. El modelo sinóptico de un Derecho Social objetivo -fruto de los afanes de armonía y solidez- se desplomaba, dejando tras de sí algunos débiles arbustos que, en la vastedad del desierto social, cedían ante los vendavales del neoliberalismo, impenitente enfermedad contemporánea. A eso se reducía la distinción de contenidos entre el sector social del ordenamiento jurídico estatal y las esferas respectivas de los ordenamientos extraestatales interior y exterior.

Al cierre de esas reflexiones, el interrogante de la mundialización depresiva del Derecho Social se plantea para realzar los vicios que su falsa recivilización acarrea y denunciar las agresiones -obra de francotiradores de confianza que, desde distintas posiciones, pretenden abatir la pieza cuya liquidación se les confía- que inutilizan los empeños en racionalizar moralmente la vida económica.

\section{6. ¿Esperar contra toda esperanza?}

No se está tocando con la mano la recuperación íntegra de los valores del Derecho Social, pero parece equitativo y justo añadir-creyendo en la esperanza- alguna reflexión sobre ese crédito grandioso-de su insustituible dignidad-que la persona humana debe ejercitar, sin tasa y sin tregua, frente a las actitudes indiferentes de la sociedad, contra lo irrecuperable del tiempo perdido y a pesar del tormento de las incertidumbres que le aquejan.

Defender la dignidad personal del trabajador significa ir en busca de cuanto deben a la persona el hoy de su escena viviente, el mañana, que aguarda a la vuelta de cada uno de sus días, y la dureza de las circunstancias que aparecen en cada momento y/o lugar del cumplimiento de su condena a vivir en libertad. La dignidad de la persona es la cosmoeminencia, sobre el resto de las cosas que hay en el universo, y la expectativa lúcida de que, sin claudicaciones ni temores, tiene un derecho inalienable a conseguir cuantos beneficios -generados dentro del mundo que habita- convienen a sus necesidades naturales y a sus más caras ilusiones.

Tan largo recorrido está marcado por los signos de los tiempos que el Derecho Social reconoce como una de las constantes que ilustran de su can- 
tidad y calidad de su contenido variable. Le acompañaron siempre -al menos, fue tal la pretensión de cuantos abrieron sus caminos- una continuidad y un denominador común existenciales. Ello supone pertenecer a una población activa en que la persona descubre -por vocación emocional y sentido de servicio social- la esencia de sus aspiraciones, comprende los mecanismos de dependencia a que obliga la dedicación productiva, rescata los valores de la autonomía individual que han decaído, y reivindica -armonizando las energías de la actualidad con la nostalgia del pasado- unas actividades sindicales que, honrando a sus motivaciones, renueven las adquisiciones hoy maltrechas por la carcoma del neoliberalismo.

Forma ello parte de una aventura compartida, cuya recta intención -difícil de ejecutar en nombre de la causa del bien frente al poder de las tinieblas - está en la valerosa decisión de cuantos, desde todos los confines de la Tierra, denuncian los usos injustos de la globalización y confían en el ocaso de su malevolencia, que, a no dudarlo, llegará algún día.

La plenificación de la dignidad se extiende a dos especies de pobres.

Los pobres experimentados - pobladores de los grupos sociales que ya han mordido el polvo de la derrota y saben de su suerte-contemplan la voladura controlada de las adquisiciones sociales que hicieron suyas los abanderados de esa causa. Preceden a los actuales pobres profesionales de vanguardia, que pueblan vastos espacios de la Tierra sin haber agotado las experiencias históricas de los primeros, ni haber soportado la amargura de las ilusiones vencidas, ni haber perdido aún la condición de escarnecidos por la insolidaridad de quienes se hallaban alejados y por la indiferencia de quienes conviven con ellos. Atraviesan las sendas de un mundo que de antiguo les era vedado, pero en el que avanzan, sin desánimo y a costa de sus vidas, al encuentro de su espacio habitable. Ni los unos se consideran sus prójimos, ni los otros han perdido la ocasión de demostrar que, llegado el momento, tienen capacidad de obrar y conducirse cono sus más enconados adversarios.

Sobre las páginas en blanco del libro que acoge el relato de sus experiencias, la oleada de los protagonistas del drama del trabajo escribirá derecho -como suele ocurrir con los renglones torcidos de los hombres- la historia de su redención, para convencer de que su dignidad personal les antepone a las personas que les oprimieron y a los bienes que se les rehusaron, cuyo efímero triunfo no destruirá la entereza de su carácter erguido y animoso.

Ni siquiera les ha dejado solos el mensaje de una Teología que -dedicada a denunciar y extinguir esa indigencia- se compromete con el afán de cuantos, lejos de abandonar toda esperanza, están en el derecho de gozar del día y la hora de su liberación.

Cuando la causa de los así oprimidos consiga la victoria merecida, porque las leyes de la Historia así van a imponerlo, habrán caído las barreras interpuestas entre la nostalgia del paraíso perdido y un modelo de sociedad cuya excelencia prevalezca sobre el culto a la vulgaridad, la detestación de la bondad y la repugnancia por lo estético. 
Exterminadas esas plagas cuasiapocalípticas, renacerán las esperanzas de que la dignidad individual constituya el título de estancia en una ciudad terrestre, donde la persona -libre de alienaciones y temores-ame, sirva, conviva y edifique.

Nada de cuanto aquí se ha referido y ordenado habría sido dable sin la contribución generosa de cuantos -que han sido muy devotos y muchoscooperaron al fin -adecuado a las exigencias y posibilidades de su tiempode este compromiso social y académico que, si giró hasta hace poco bajo un signo determinado, no puede darse por irremisiblemente terminado y admite otros modos o versiones de prolongación.

De ahí, que el desafío de un espectacular Derecho de Gentes de las relaciones de trabajo siga aguardando las respuestas conducentes a la supervivencia y la reconstrucción álgida de un mundo que, pese a los hábitos de devastación que le inundan, cree todavía y seguirá creyendo en la esperanza. 